\title{
Large flake Acheulean in the middle of Tagus basin (Spain): Middle stretch of the river Tagus valley and lower stretches of the rivers Jarama and Manzanares valleys
}

\author{
Susana Rubio-Jara a, Joaquín Panera ${ }^{\text {b, * }, ~ J u a n ~ R o d r i ́ g u e z-d e-T e m b l e q u e ~}{ }^{\text {, }}$, \\ Manuel Santonja ${ }^{\mathrm{b}}$, Alfredo Pérez-González ${ }^{\mathrm{b}}$ \\ a Instituto de Evolución en Africa (I.D.E.A.), Museo de San Isidro, Plaza de San Andrés 2, 28005 Madrid, Spain \\ ${ }^{\mathrm{b}}$ Centro Nacional de Investigación sobre la Evolución Humana (C.E.N.I.E.H.), Paseo Sierra de Atapuerca, s/n, 09002 Burgos, Spain \\ c Asociación Nacional el Hombre y el Medio, Madrid, Spain
}

\section{A R T I C L E I N F O}

\section{Article history:}

Available online $\mathrm{xxx}$

\section{Keywords:}

Pleistocene

Acheulean

Palaeolithic

Tagus, Jarama and Manzanares rivers

Iberian Peninsula

\begin{abstract}
A B S T R A C T
The highest concentration of Palaeolithic sites known in the Iberian Peninsula is located in the lower stretches of the Manzanares and Jarama rivers. This area, together with a number of zones in the Tagus valley, constitutes one of the most important archives for the knowledge of the European Pleistocene. The purpose of this paper is to establish the chronological frame and the technological strategies implemented in manufacturing lithic tools during the Acheulean techno-complex in the middle stretch of the Tagus basin. Use of large flakes for making bifaces is common in the Acheulean assemblages from this area, as well as in the rest of the Iberian Peninsula and the south of France.

The earliest Acheulean evidence has been dated to between MIS 15 and MIS 13. From MIS 11/MIS 9 on, this techno-complex is widespread in the region, until MIS 6, when the last evidence has been recorded. Handaxes, cleavers on flake and trihedral picks dominate in the châines opératoires of façonnage, which are present in significant percentages. Short châines opératoires of débitage prevail in quartzite, and discoid and polyhedric in flint. Most retouched tools are seldom elaborate. Lithic assemblages with châines opératoires of façonnage exclusively represented by handaxes start to be recorded towards the end of the Middle Pleistocene. These handaxes are more elaborate than previous and the retouched tools are more complex.

Among the activities identified in the sites excavated in overbank facies, exploitation of large mammals, particularly proboscideans, is outstanding, as well as the manufacture of lithic tools and the exploitation of primary flint outcrops. The recording of long recurrent settlements on the same location is remarkable.
\end{abstract}

(C) 2015 Elsevier Ltd and INQUA. All rights reserved.

\section{Introduction}

The beginning of the Acheulean period in Europe is still being debated (Moncel et al., in press; Mosquera et al., in press). In Southern Europe it is recorded since at least MIS 12, although older dates have been published for sites belonging to this technocomplex (Falguères et al., 2004; Barsky and de Lumley, 2010; Lefèvre et al., 2010; Moncel et al., 2013; Pereira et al., 2015). However, confirmation of these dates by alternative dating

\footnotetext{
* Corresponding author.

E-mail address: joaquin.panera@cenieh.es (J. Panera).
}

methods would be desirable (Demuro et al., 2014). In other cases, the Acheulean character of the lithic industry is not decisive enough for corroboration (Vallerdú et al., 2014; Santonja et al., in press).

The diversity of technological strategies in the manufacturing of lithic tools, particularly handaxes, has prompted some authors to allude to "Acheuleans" rather than a single Acheulean period in Western Europe (Moncel et al., in press). The Acheulean in the Iberian Peninsula and the south of France shows certain technological characteristics in common with the African Acheulean, which are not found in the rest of Europe (Clark, 1994; Sharon, 2010). This suggests possible connections with North Africa via 
the Strait of Gibraltar (Santonja and Villa, 2006; Doronichev and Golovanova, 2010; Sharon, 2011; Bar-Yosef and Belfer-Cohen, 2013).

The most characteristic morphotypes of the Acheulean, handaxes, cleavers, and picks, are frequently made on large flakes in Africa (Roche et al., 2003; Semaw et al., 2009). Production of these blanks has been considered one of the most important features of this techno-complex (Isaac, 1969; Leakey, 1975). The "large flake" definition of Kleindienst (1962), as one larger than $10 \mathrm{~cm}$, has been accepted by most researchers. In Europe, the use of large flakes for bifaces is common only in the Iberian Peninsula (Santonja and Pérez-González, 2010) and in the basins of the rivers Garonne, Rhône, Roussillon and Tarn, in Southern France (Tavoso, 1986; Mourre, 2003; Turq et al., 2010). The availability of coarse grained rocks, combined with the presence of appropriate -blanks, as sometimes occurs in the Iberian Peninsula and Southern France, has been considered as the key factor concerning this distinction. However, large flakes can also be knapped from fine-grained rocks (Rolland, 1995; Sharon, 2010), as occurs at sites such as La Noira (Moncel et al., in press), or at Caune de l'Arago, levels P and Q (Barsky and Lumley, 2010; Barsky, 2013). However, only a few of these were used for manufacturing handaxes and cleavers.

Since the end of the Lower Pleistocene, lithic assemblages composed of cores and flakes have been recorded in Europe (Parfitt et al., 2010; Turq et al., 2010; Jiménez-Arenas et al., 2011; Toro et al., 2011; Ollé et al., 2013). These industries could actually be the substratum of the European Ancient Middle Palaeolithic (EAMP), which has been recorded in the continent since the final MIS 9 or early MIS 8 (Moncel et al., 2005; Bourguignon et al., 2008; Koehler, 2008; Richter, 2011; Santonja et al., in press). Therefore, in Europe, the earliest Acheulean coexisted with flake and core industries which existed on the continent since the final Lower Pleistocene, and later, since the end of MIS 9, with EAMP. As a result of this coexistence, the European lithic assemblages developed between MIS 8 and MIS 6 show different technological solutions derived from mutual influences (Santonja et al., in press).

In the middle stretch of the Tagus basin, as in the rest of the Meseta of the Iberian Peninsula (Santonja and Pérez-González, 2010), using large flakes for manufacturing bifaces is a common practice from the first to the last examples of the Acheulean, regardless the availability of coarse-grained rocks, although access to these raw materials can be noticed from its proportional representation. The purpose of this paper is to identify the timeframe and the technological strategies used in manufacturing lithic tools during the Acheulean techno-complex in the middle stretch of the Tagus basin.

The highest density of Palaeolithic archaeological sites known in the Iberian Peninsula lies within the fluvial deposits of the last stretch of the Manzanares and Jarama rivers, as well as in some areas of the Tagus valley (Fig. 1) (Rubio-Jara et al., 2002). This is due on the one hand to the geological characteristics of these valleys, and on the other hand to modern day demand for aggregates in Madrid, which have favoured first the accumulation of Pleistocene deposits, and then access to large sections of those deposits in sand and gravel quarries (Rubio-Jara et al., 1999; Santonja and Vega, 2002).

The Pleistocene at the Tagus basin has been studied since 1850 , when two elephants were excavated in Tejar de las Ánimas, at Cerro de San Isidro in Madrid (Paz Graells, 1897; Santonja et al., 2001). Shortly after, the first knapped lithic artifacts were recognized, including a flint cleaver, which were published in 1863 (Verneuil and Lartet, 1863). Between 1917 and 1931, under the initiative and supervision of Hugo Obermaier (1879-1946), several sites were discovered and investigated (Obermaier, 1925). These works were carried out during the 1950's and 1960's, with an approach distant from the accepted premises of the time, although with certain international repercussion thanks to the 4th International Congress of Prehistoric and Protohistoric Sciences and the 5th International Quaternary Congress (INQUA), which were held in Madrid in 1954 and 1957 respectively. From 1970 there was a renewal of Palaeolithic research, but despite the innovative approaches (Santonja et al., 1980), the 20th century ended with disappointing results regarding the knowledge of this period.

During the first decade of the current century, data regarding Pleistocene human occupation in this area has been significantly updated. Since the late nineties, systematic research projects have been implemented in the middle and lower stretches of the Jarama and Manzanares rivers (Uribelarrea, 2008; Panera, 2009; RubioJara, 2011), as well as in their interfluve (Bárez et al., 2010; Baena Preysler et al., 2015), and in the middle stretch of the Tagus river (Rodríguez de Tembleque, 2008, 2010; López-Recio et al., 2015). The research programs carried out during the last years in the Manzanares and Jarama valleys, as well as in the Tagus valley, are considered as regional studies of the Pleistocene. They have been based on systematic field surveys on sections of fluvial deposits, where a large number of industrial assemblages have been recorded in stratigraphical context. Many of them in gravel bars, and others on overbank facies. Finally, a series of numerical dates have updated the general knowledge of the Pleistocene in the South Submeseta of the Iberian Peninsula, in particular the Acheulean, which has highlighted this area as one of the most important European archives for the knowledge of this period.

The lithic industries found in stratigraphy in Pleistocene fluvial deposits of the low stretches of the rivers Manzanares and Jarama valleys, and between the mouth of the river Algodor and Puente del Arzobispo in the river Tagus valley (Fig. 1), are described in this paper, based on their geomorphological and chronological frameworks. In this paper we shall use the term bifaces (handaxes, cleavers and trihedral picks) in the context of current knowledge about the Acheulean, as it has been recently considered by several scholars (cf. Díez-Martín and Eren, 2012: 325 ff.; Sahnouni et al. 2013: 309 ff. and references therein).

\section{Geomorphology and chronostratigraphic sequence of the terraces at the Tagus, Jarama and Manzanares rivers}

The Tagus basin is located within the South Sub-Meseta of the Iberian Peninsula. It is bounded by the Sistema Central (Gredos and Guadarrama mountains) to the north, by the Cordillera Ibérica to the east, and by Montes de Toledo to the south.

The geological uniqueness of part of the valleys of the Tajo, Jarama and Manzanares rivers has contributed to the preservation of lithic industry and faunal remains from the Pleistocene. These valleys are characterised by the development of a great number of fluvial terraces, related to Quaternary climatic oscillations; techtonics (Alia, 1960; Pérez-González, 1980; Silva et al., 1988a,b; PérezGonzález, 1994), isostatic rising and blocks adjustment, and lithological structural controls (Pérez-González, 1971), which were responsible for their configuration.

In the Tagus valley, near the city of Toledo, 12 terrace levels have been distinguished (Pérez-González, 1994; Roquero et al., 1999) between $+4-6 \mathrm{~m}$ and $+125 \mathrm{~m}$. Upstream from Toledo, in Aranjuez, karstification of the Miocene evaporite-gypsum has led to the thickening of the fluvial terraces (Pérez-González, 1971).

In the high-middle trench of the Jarama valley, 19 terrace levels have been recorded between $+3-5 \mathrm{~m}$ and $+190 \mathrm{~m}$ (Fig. 2). In the lower part of the valley, Miocene evaporite-gypsum, which crop out to the east and south of Madrid, have facilitated synsedimentary subsidence processes in the underlying karst, affecting terraces with a relative level lower than $+40 \mathrm{~m}$. These terraces, which upstream are of stepped and perched types, overlap the oldest ones, giving rise 
to the Complex Terrace of Arganda (hereafter CTA) (Pérez-González, 1971, 1994; Panera et al., 2011), over which the current floodplain is set (Figs. 1 and 2). CTA is made up of successively stacked fluvial sequences, named from bottom to top Arganda I, II, III, which match up with terraces $+30-32 \mathrm{~m},+23-24 \mathrm{~m}$, and $+18-20$ m respectively (Pérez-González and Uribelarrea, 2002; Panera et al., 2011). Arganda I contains several floodplain deposits, whereas Arganda II and III consist mainly of sand and gravel bars matching channel facies. Finally, Arganda IV is made up of fluvial fan deposits which can exceed $20 \mathrm{~m}$ in thickness, and originate in the oldest Miocene and Quaternary relieves from the left margin of the Jarama River, also prone to contain in situ archaeological sites (Panera et al., 2005).

In the Manzanares valley, upstream from Madrid, 13 terrace levels have been recorded between $+4-5 \mathrm{~m}$ and $+95 \mathrm{~m}$ (PérezGonzález, 1994). This system of stepped terraces gives way to a system of complex terraces, named Complex Terrace of Butarque (hereafter CTB) (Goy et al., 1989). The terraces formed over evaporitic rocks $+25-30 \mathrm{~m},+18-20 \mathrm{~m}$ and $+12-15 \mathrm{~m}$, are overlapped and affected by the synsedimentary subsidence, resulting in a huge thickness increase of dozens of meters. Silva (2003) names this as the Manzanares Complex Terrace (TCMZ).

The chronostratigraphy of these fluvial valleys has been established on the basis of the terrace sequence combined with palaeomagnetism, biochronological and numerical data. The terrace $+75-80 \mathrm{~m}$ (Salto de la Zorra), in the Tagus valley, contains Equus stenonis (Alférez, 1978, 1999), and belongs to the final Lower Pleistocene period, before the Cromerien stage (Aguirre, 1989). A mandible of a Mammuthus meridionalis, of Lower Pleistocene date was found at the terrace $+60-65 \mathrm{~m}$, in Valdelobos Superior (Alférez, 1977, 1999). This is consistent with the recorded reverse polarity, which has been interpreted (Pinilla et al., 1995) as belonging to Chron Matuyama. In the Jarama valley, the Brunhes-Matuyama reversal (0.780 Ma ago), took place after the last moment of the $\mathrm{T}+60-65 \mathrm{~m}$ terrace sedimentary process and before the formation of the entrenched terrace $+50-55 \mathrm{~m}$ (<0.780 Ma; Pérez-González et al., 2013). This data is consistent with that retrieved from the River Arlanzón valley, where terraces with relative levels $+85-90 \mathrm{~m},+105-110 \mathrm{~m}$, and $+125-130 \mathrm{~m}$ belong to the Chron Matuyama and precede the Subchron Jaramillo, specifically, are older than $1.070 \mathrm{Ma}$. Furthermore, the terrace +60-67 m, which shows reverse polarity (Benito-Calvo et al., 2008), has been dated by ESR (Electron Spin Resonance) to at least $0.780 \mathrm{Ma}$ (Moreno et al., 2012), whereas a terrace $+50-54 \mathrm{~m}$ with normal polarity (Benito-Calvo et al., 2008) has been dated by ESR to $0.670 \mathrm{Ma}$ (Moreno et al., 2012).

In the terrace $+40-45 \mathrm{~m}$ of the Tagus River, an assemblage of macro and micromammals characteristic of the Middle Pleistocene was found (Alférez, 1977, 1999; Sese et al., 2000, 2004). The terrace $+25-30 \mathrm{~m}$ has been dated by IRSL (post-Infrared Stimulated Luminiscence) and AAR (Amino Acid Racemisation) (LópezRecio et al., 2015). The dates obtained by IRSL applied on feldespar K grains are $>280 \mathrm{ka}$ and $292 \pm 17 \mathrm{ka}$ respectively, whereas the AAR date, taken from three Equus molars, provides a date of $226 \pm 37 \mathrm{ka}$, in Pinedo, suggesting that the fluvial deposits of the terrace $+25-30 \mathrm{~m}$ were laid between the isotopic stadia 9 and 7 .

In the Jarama valley, the evolutive stage of micromammals from Áridos I -in the Unit Arganda I of CTA ( $\approx \mathrm{T}+30-32 \mathrm{~m}$ ) (López Martínez, 1980; Santonja et al., 1980), suggests a Late-Middle, but not Final Pleistocene date. This is consistent with two dates obtained by AAR, which suggest a period between $294 \mathrm{ka}$ and $425 \mathrm{ka}$ $(379 \pm 45$ and $332 \pm 38 \mathrm{ka})$, overlapping with the final stretch of MIS 11, between $335 \mathrm{ka}$ and $370 \mathrm{ka}$ (Panera et al., 2011). In the Arganda II Unit ( $\approx \mathrm{T}+23-24 \mathrm{~m}$ ), the micromammal assemblage from Valdocarros (Sese et al., 2011) places this unit some time later than Áridos I, in the Late Middle Pleistocene. AAR analysis applied to two samples taken from two consecutive flood sequences provides dates of $262 \pm 68 \mathrm{ka}$ and $254 \pm 47 \mathrm{ka}$ respectively, overlapping with the period between $255 \mathrm{ka}$ and $269 \mathrm{ka}$ (Panera et al., 2011). Biostratigraphic and numerical dates have not been retrieved from the Arganda III Unit ( $\approx+18-20 \mathrm{~m}$ ) due to the high cementation characteristic of this deposit. Aluvial deposits from Arganda IV have been dated by OSL (Optically Stimulated Luminescence) between $112+36-22 \mathrm{ka}$ and $8 \pm 0.7 \mathrm{ka}$ (Panera et al., 2005, 2011). Taking into consideration on the one hand the climatic needs of micromammals and herpetofauna from Áridos 1, Valdocarros and HAT (Arganda I, II and IV respectively), characteristic of mild climate (Blain et al., 2012), and on the other hand the overlapping of the available numerical dates, Arganda I falls within the late MIS 11 or early MIS 9; Arganda II would match some interestadial period from MIS 8 (although late MIS 9 or early MIS 7 should not be ruled out), and the basal third of Arganda IV, downstream from Valdocarros, would match with Is 20 of MIS $5 a$, although some parts (such as the top) could be dated to the Early Holocene (Panera et al., 2011).

Remains of Praedama sp. (the same as Megaloceros according to Lister, 1994 and Made, 2001) were found in Transfesa/Tafesa, in the $\mathrm{T}+25-30 \mathrm{~m}$, in the Manzanares valley. These remains, together with the scarcely evolved morphology of E. (Paleoloxodon) antiquus, suggest this site dates to around the Bihariense-Oldenburgiense limit (MIS 11-13; Sese and Soto, 2000). Regarding Tafesa, Mazo (2010) dates this site before MIS 11, due to the presence of Megaloceros savini, which is chronologically earlier than Megaloceros giganteus, and is recorded in MIS 11 (Lister, 1994; Made, 2001). There are neither numerical dates nor biostratigraphical data for terraces $\mathrm{T}+35-40 \mathrm{~m}$ and $\mathrm{T}+18-20 \mathrm{~m}$ of the River Manzanares. The CTB could be composed of at least $\mathrm{T}+18-20 \mathrm{~m}$ and $+12-15 \mathrm{~m}$. This deposit can reach up to $70 \mathrm{~m}$ (Uribelarrea, 2008), although only $15 \mathrm{~m}$ are visible, dated between the Final Middle Pleistocene and MIS 4. A minimum date of $125 \mathrm{ka}$ has been obtained by TL for the bottom of the CTB, at the beginning of this unit, in sequence 3 of Estanque de Tormentas de Butarque (ETB) (Domínguez et al., 2007, 2009). There are two TL dates for sequence 2 of ETB, $78.7+10.7 /$ -9.7 ka BP and 84.6 + 12.6/-11.2 ka BP (De los Arcos et al., 2008; De los Arcos et al., 2010). These would be minimum dates, according to the biochronological data provided by the association of microfauna and the evolutive stage of Microtus brecciensis, which suggests a date in the last quarter of the Middle Pleistocene (Laplana et al., 2015). In Los Estragales 1, there are two TL dates for the visible bottom of CTB, overlapping between $111.1 \mathrm{y}$ los $133.3 \mathrm{ka}$ (Pérez-González et al., 2008). In EDAR Culebro 1, there is one date obtained by OSL of $120.541 \pm 6.851 \mathrm{ka}$, and another one obtained by AAR, which stretches between $133 \pm 28$ and $105 \pm 10 \mathrm{ka}$ (Manzano et al., 2010). Two further dates, of $133 \mathrm{ka}$ and $134 \mathrm{ka}$, were obtained by TL in the Arriaga sand quarry (Silva et al., 2012). In Arriaga I, an association of microfauna with the presence of Microtus brecciensis has been recorded, thus dating this site to the Final Middle Pleistocene (Sese and Lopez-Martínez, 2013). However, other researchers (Laplana et al., 2015) consider the remains to be Microtus cabrerae, belonging to the Upper Pleistocene. Nonetheless, the lack of biometrical data of the Iberomys (Microtus) lineage towards the end of the Middle and beginning of the Upper Pleistocene means that a date in the Late Middle Pleistocene has not been completely ruled out. The middle stretches of the outcrop of the CTB recorded at PRERESA, dated to $85.3 \pm 4.7 \mathrm{ka}$ and $84.1 \pm 5.6 \mathrm{ka}$ (Yravedra et al., 2012; Panera et al., 2014) belong to MIS 5b-5a; and so does Los Estragales 2, dated to $90.6 \pm 9.1$ ka (Pérez-González et al., 2008). Finally, the apparently non-eroded tops of CTB, are dated to $64.5+15.2 /-11.3$ and $60.1 \pm 3.4 \mathrm{ka}$ in Los Estragales (PérezGonzález et al., 2008). T $+12-15 \mathrm{~m}$, which is overlapped and entrenched within the СТВ in its initial stretch, has provided two 


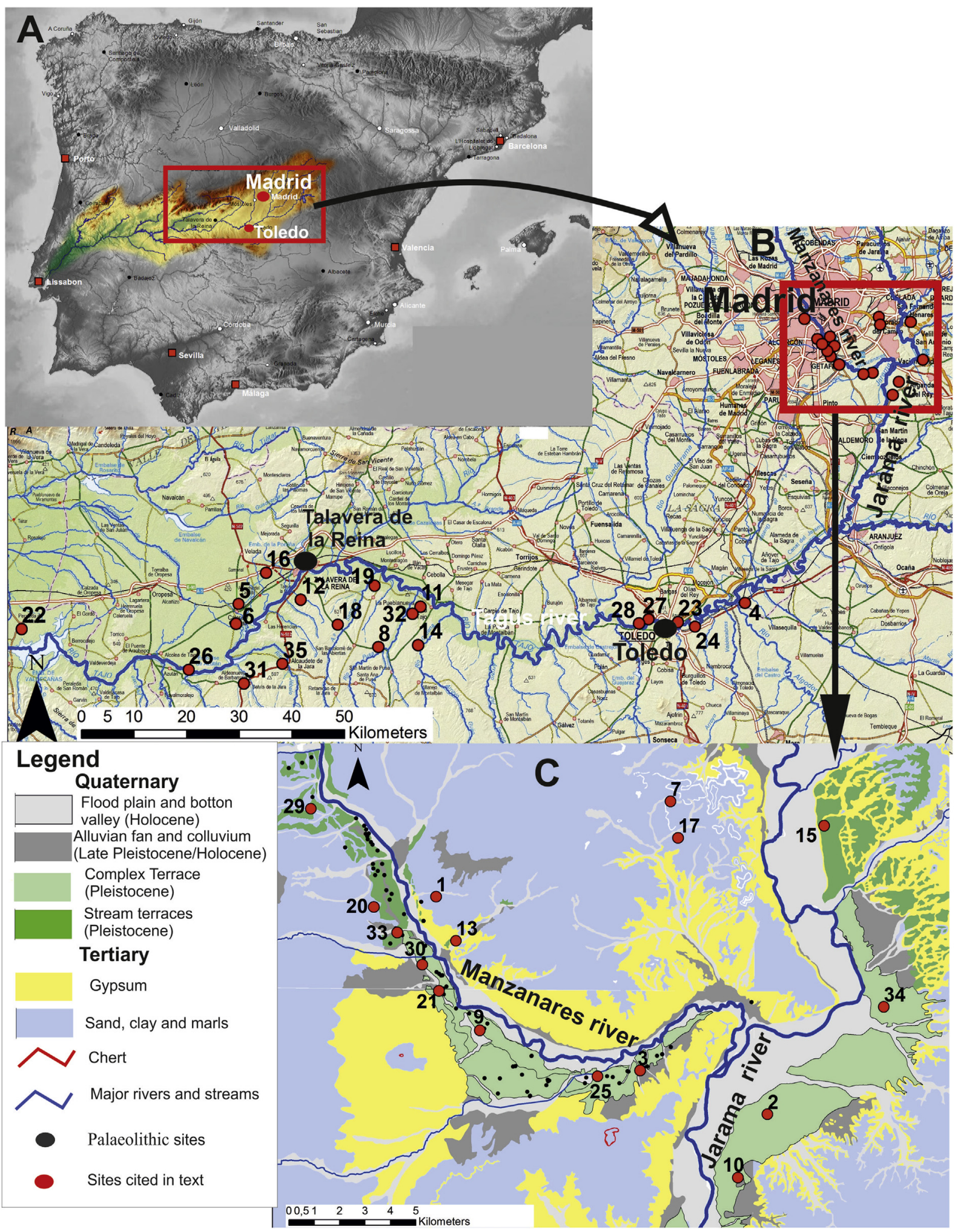

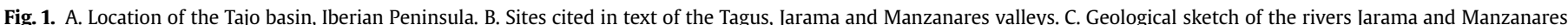

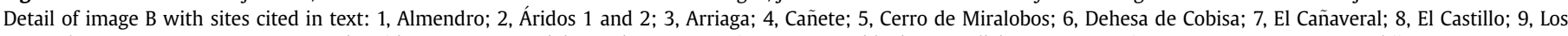

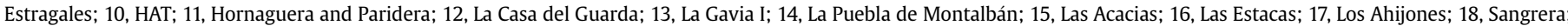

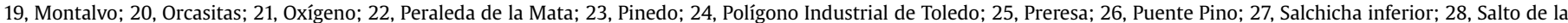
Zorra; 29, San Isidro; 30, Santa Elena; 31, Tamujoso; 32, Quinto de Ochavo; 33, Transfesa/Tafesa; 34, Valdocarros; 35, Gébalo. 


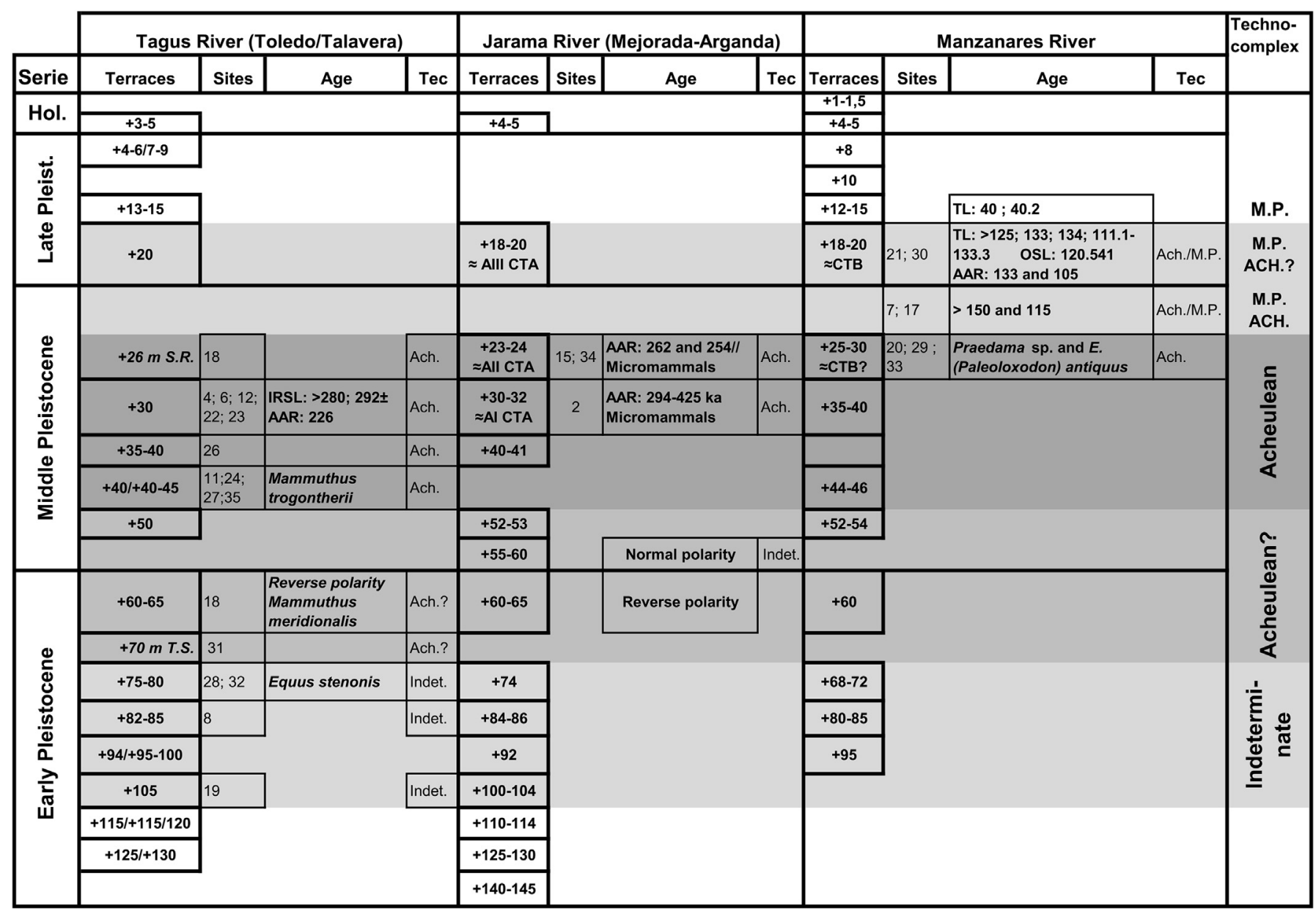

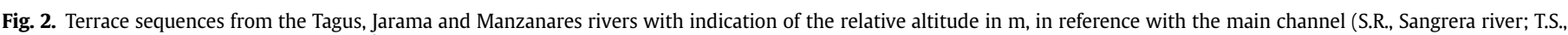

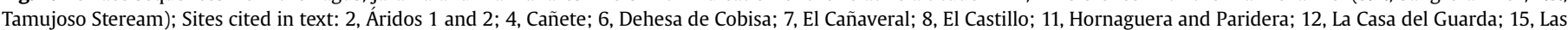

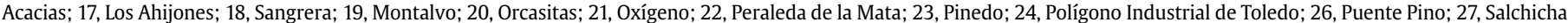

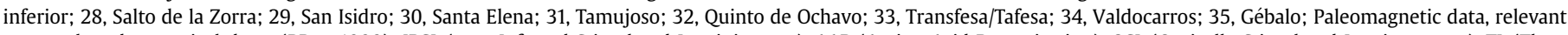

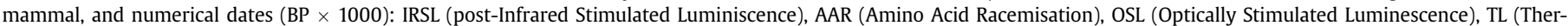
moluminescence); Technocomplex: Ach (Acheulean), M.P. (Middle Palaeolithic).

numerical dates, one of $40 \pm 2.7$ ka (Pérez-González et al., 2008), and another one $40.2 \pm 4.6$ ka (Domínguez et al., 2007, 2009).

\section{The Acheulean in the Tagus basin}

\subsection{Human presence before MIS 13: the first Acheulean traces}

No site from this period has ever been excavated. The information available derives from intensive surveys carried out on stratigraphical sections. The scant finds of lithic industry have been located in the middle and high terraces of the River Tagus and in some of its tributary rivers on the left bank, within the stretch of the basin between the mouth of the River Algodor and the town Puente del Arzobispo (Santonja and Pérez González, 1997, 2000-2001; Rodríguez de Tembleque, 2008; Rodríguez de Tembleque et al., 2010).

The oldest remains have been recorded in $\mathrm{T}+105 \mathrm{~m}$ of the River Tagus, at Montalvo (La Pueblanueva), where a chopper, an exhausted core and a flake fragment were found (Santonja and Pérez-González, 1997). Two large retouched flakes and two large quartzite scrapers were found in the $\mathrm{T}+83 \mathrm{~m}$ of the River Pusa (at El Castillo, Belvis de la
Jara). Lithic industry has been discovered at several locations with similar stratigraphical position in the terrace $T+75-80 \mathrm{~m}$ of the River Tagus and its affluents (Rodríguez de Tembleque et al., 2010). At El Espinar (Almonacid del Tajo), two choppers and one denticulate were found in a level of gravel (Santonja, 1981a,b; Santonja and Querol, 1982; Santonja and Pérez-González, 2000-2001), as well as two simple flakes, one multifacial core, one quartzite bec and another retouched item (Rodríguez de Tembleque et al., 2010). Downstream from Toledo, in Salto de la Zorra, remains of Equus stenonis Cocchi (Alférez, 1977, 1978) have been recorded, as well as three quartzite flakes -one of which is retouched-, one retouched flint flake and a further nine pieces which were unclearly knapped. Finally, three unifacial quartzite cores -of which one was quite large and another one bipolar-were found at Quinto de Ochavo (Talavera de la Reina) (Rodríguez de Tembleque et al., 2010). These may indeed be the first properly contextualized remains of human occupation in a fluvial environment in the Meseta, and should be dated within the lower Pleistocene (between 1.3 and $0.9 \mathrm{Ma}$ ). In all cases, these are small assemblages (no more than ten pieces), except for the quartzite pieces, showing pronounced fluvial rolling and doubtful in many cases. 


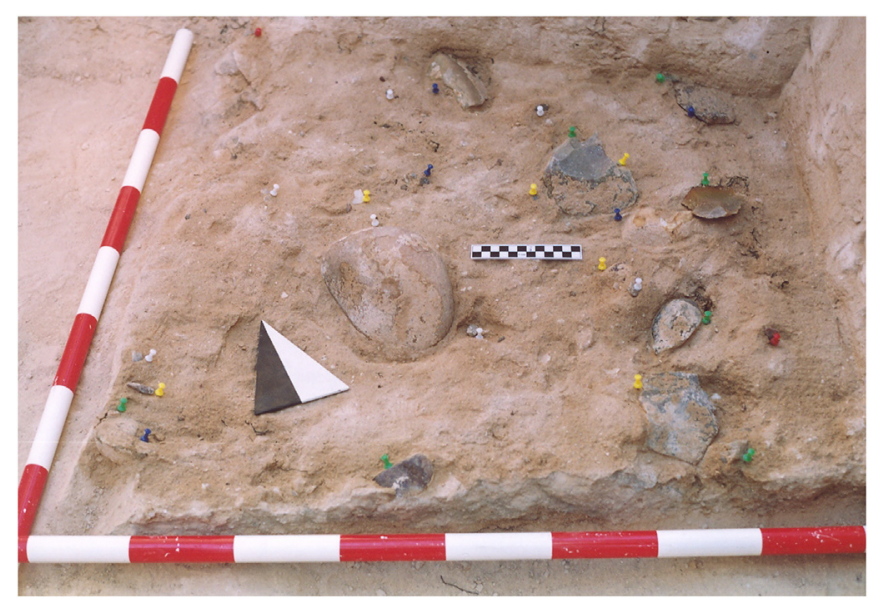

Fig. 3. Level PNA at Puente Pino during the excavation campaign in 2005.

In the terraces of the Tagus valley, lithic industry has been recorded in practically all levels comprised between $+80 \mathrm{~m}$ and $+50 \mathrm{~m}$, both relative levels included, although scarce and, with exceptions, showing moderate to pronounced fluvial wearing (Rodríguez de Tembleque, 2008; Rodríguez de Tembleque et al., 2010). There are also few pieces per level, nearly all made of quartzite, mainly flakes and cores. In $\mathrm{T}+70 \mathrm{~m}$ of the stream Tamujoso (affluent of the River Gébalo on its left bank, which joins the River Tagus), seven quartzite pieces have been recorded, five of which have been clearly stratigraphically located. These include a multifacial core, three flakes and one biface on flake with measurements of $114 \times 85 \times 40 \mathrm{~mm}$ (Figs. 1 and 2), which could actually be the first evidence of the Acheulean in the Tagus basin (Rodríguez de Tembleque et al., 2010). Furthermore, discoid cores, one nucleiform handaxe and several tools on flake are included among the 18 pieces found at the $\mathrm{T}+60-65 \mathrm{~m}$ of River Sangrera (Santonja and Pérez-González, 2000-2001), in San Bartalomé de las Abiertas (downstream Talavera de la Reina).

In the Jarama valley $-\mathrm{T}+55-60 \mathrm{~m}$ - 33 pieces have been documented. Bifaces have not been identified among them, but discoid, bifacial, orthogonal multifacial and kombewa cores have been recorded (Panera, 2009).

Lithic industry within a stratigraphical context has been recorded at different locations within the terrace $+40-45 \mathrm{~m}$ of the River Tagus. These terrace levels may correspond with MIS 15-12 (see discussion). Dozens of pieces showing clear Acheulean features have been recovered from Hornaguera and Paridera (Malpica de Tajo) (Santonja and Pérez-González, 1997; Rodríguez de Tembleque, 2008). Most were made of quartzite. The assemblage is composed mainly of unretouched flakes; also cores, including one outstanding example from which supports for cleavers were -detached; one chopper, one cleaver on flake, one trihedral pick and a thick ovate handaxe-Lithic industry in stratigraphical context was recorded during the excavation of a skull of Mammuthus trogontherii close to the Toledo Industrial Estate (Santonja, 1981a; Santonja and Querol, 1982; Santonja and Pérez-González, 2000-2001). Also, in Buenavista inferior and Salchicha inferior chopping tools (Santonja, 1981a) and some trihedral pick and handaxes (Alférez, 1977) have been recorded. In other similar terraces an Acheulean-looking industry has been recorded, although with small numbers of pieces, as in the Gébalo and Tagus valleys, both in the area of Talavera de la Reina (Las Estacas, Cerro de Miralobos, etc.), and in La Puebla de Montalbán (Rodríguez de Tembleque, 2008).

\subsection{Lithic assemblages recorded between MIS 13 and MIS 6}

\subsubsection{Terrace $+35-40 \mathrm{~m}$}

The site of Puente Pino is related to this level, near Puente del Arzobispo, some few metres downstream the mouth of the River Uso. Two sites have been distinguished: Puente Pino TGS and PNA. TGS is located on the terrace $+40 \mathrm{~m}$ of the River Tagus, associated with deposits of lateral channels which have eroded the terrace. It consists of a deposit of fluvial gravels sealed by a thick level of silty clay with inclusions of very fine eolic sand. PNA seems to be associated with deposits in a terrace $+35 \mathrm{~m}$, entrenched in the T $+40 \mathrm{~m}$ of the River Tagus. The lithic assemblage lies over a deposit of fluvial sand and is covered by silty clay with very fine sand. Both levels show a high average density of Acheulean industry (Figs. 3 and 4): at least 70 pieces per $\mathrm{m}^{2}$ in PNA, and about 477 pieces per $\mathrm{m}^{3}$ in TGS (Rodríguez de Tembleque, 2004; Rodríguez de Tembleque, 2005a,b, 2008).

The lithic industry is made mainly of quartzite, but also contains quartz and to a lesser extent flint and other rocks. In both levels -but particularly in PNA-all the regular elements of the lithic production processes are represented in consistent proportions. Several types of tools have been documented: hammerstones, some anvils, debris, chunks, un-retouched and retouched flakes (scrapers, denticulates, backed knives, awls and so forth), cores, of which some have been apparently retouched, and nucleiform pieces sometimes with a trihedral point, choppers (mainly unifacial), cleavers on flake (types 0 , I and II), handaxes of different types and sizes, sometimes partial, many of them knapped on flakes; and few trihedral picks, as well as multi-purpose tools. The multifacial type predominates among the cores, followed by the bifacial type, often showing centripetal removals and Levallois features. A significant number of the cores are elemental or simple, and others are exhausted or in a terminal phase of exploitation. Remarkable intensity in flaking and use of the cores can be inferred from the characteristics present in the flakes and progressive cores. Frequent use of large quartzite flakes for knapping bifaces is outstanding. Quartz, and especially flint industries are smaller in size than that made of quartzite, in accordance with the lower availability and smaller size of those raw materials. Bifaces made of quartz or flint have not been recorded.

\subsubsection{Terrace $+25-30 \mathrm{~m}$}

The best-known site in the Tagus valley is Pinedo, in Toledo (Querol and Santonja, 1979). A lithic assemblage of some 5961 pieces was retrieved, as well as some faunal remains. All the remains were found in secondary positions and linked to channel bars (Díaz and Pérez-González, 1979), and were retrieved from $110 \mathrm{~m}^{3}$ of an area $25 \mathrm{~m}^{2}$ The most common raw material is quartzite (68\%), followed by flint (25\%) and quartz (7\%). It is inferred from this data that flint was either highly selected or brought to the site, as its presence in the gravel deposits is lower than 2\% (Querol and Santonja, 1979). The industry shows moderate fluvial wear and is characterised by a minimal presence of Levallois flakes, an abundance of entame flakes, and a lack of Levallois cores, the most predominant being cores with multifacial and discoid schemes. The diversity of tools on flake is outstanding, scrapers being the predominant type. Among the macrotools, the chopper is the most abundant category, followed by trihedral picks, handaxes and cleavers on flake. With regard to the handaxes -all of which were made of quartzite except two of flint-thick ones prevail, with amygdaloid, ficron or abbevillian silhouettes. They are poorly elaborated, which explains the high number of partial specimens and abbevillian types with asymmetric edges and silhouettes. The cleavers on flake barely show any retouch, and half show wear traces in their cutting edges. Straight edges predominate, as well as 

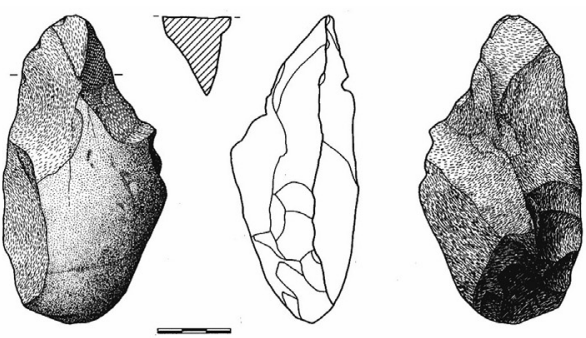

1
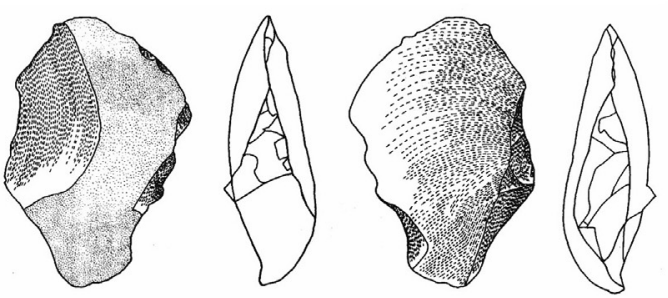

2
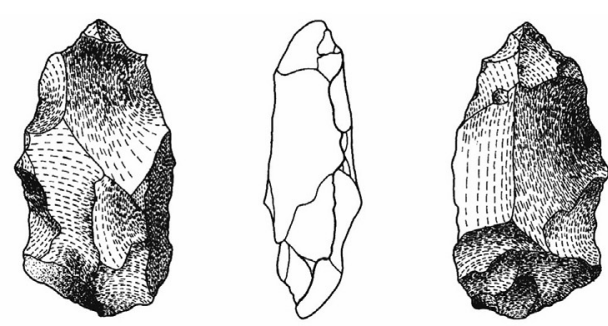

3
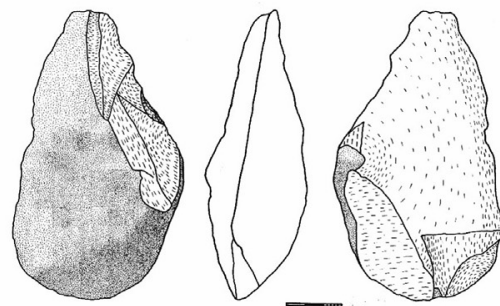

4
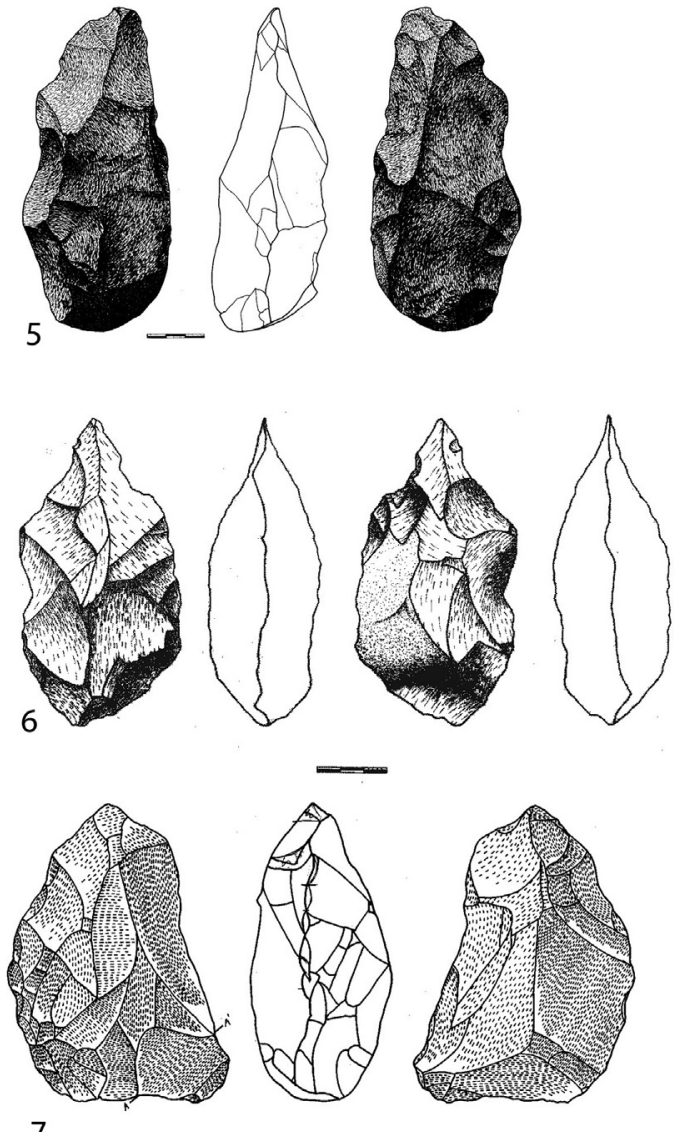

7
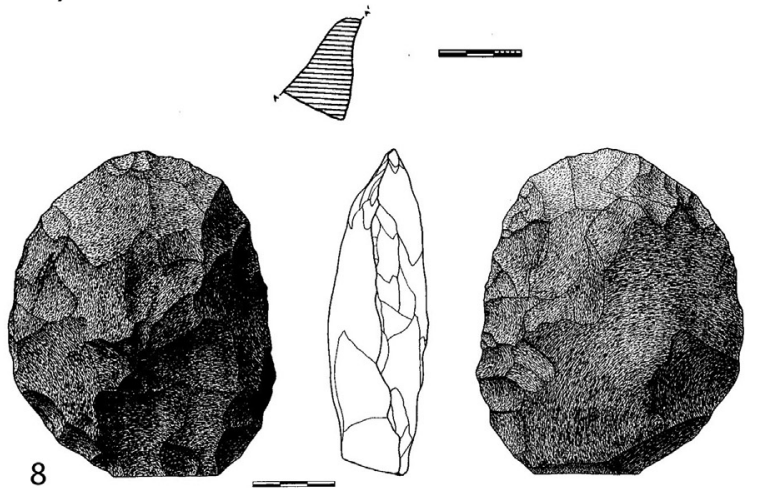

Fig. 4. 1-4. Bifaces from level TGS at Puente Pino site in Alcolea del Tajo, Toledo (Spain); 5-8 Handaxes from level PNA at Puente Pino. 7 and 8 are knapped on flake.

thick bases and Tixier's 0 and I types (Querol and Santonja, 1979; Fig. 5).

Two sites have been recorded in the left bank of terrace $+25-30 \mathrm{~m}$ of the River Tagus, both in road sections and gravel quarries. This is probably the same terrace as Pinedo, which is located about $10 \mathrm{~km}$ downstream and on the right bank. The sites are Cañete Bajo (Santonja and Pérez-González, 1997, 2000-2001; Rodríguez de Tembleque, 2008) and Cañete Alto (Rodríguez de Tembleque, 2008). Some faunal remains and Acheulean industry have been recorded in a secondary position, particularly in bed load deposits. These industries show densities, alterations and general characteristics similar to those from Pinedo. Two sedimentary units in a channel facies deposit have been distinguished in Cañete Bajo, or Cien Fanegas. Remains of E. (Paleoloxodon antiquus) were found in the bottom $5 \mathrm{~m}$ sand deposit, and 130 lithic pieces were retrieved from towards the top of the $3 \mathrm{~m}$ gravel deposit, all quartzite but six of flint, among which old industries were frequently used as blanks (Baena Preysler et al., 2010c). Multifacial cores predominate, and discoid and Levallois are absent. The presence of specimens aimed at obtaining supports for bifaces is remarkable. Retouched tools are scarce. With regard to the macro tools, which are poorly elaborated, use of old industries and flakes as support is frequent. The predominant categories are trihedral picks, followed by handaxes, cleavers on flake and choppers. The trihedral picks, which have been compared to those from Tafesa (Baena Preysler and Baquedano, 2004), are small in size, no larger than $15 \times 10 \mathrm{~cm}$ (Fig. 5). The handaxes, with a morphology next to that of the trihedral picks, are poorly executed, and have been made through non-alternating removals. The cleavers on flake also show small sizes and are poorly executed, the Tixier's 0 and I types being 

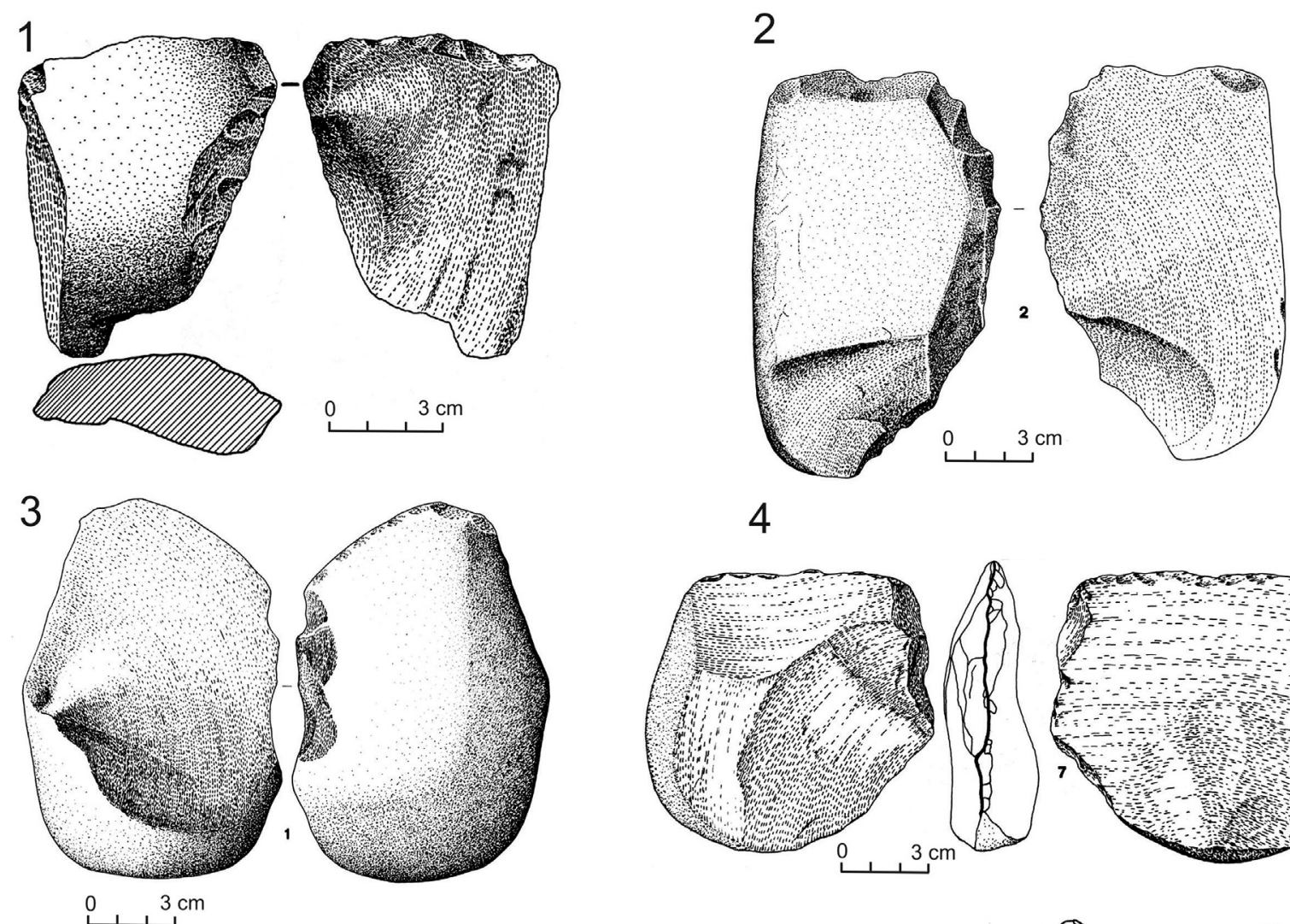

4

5

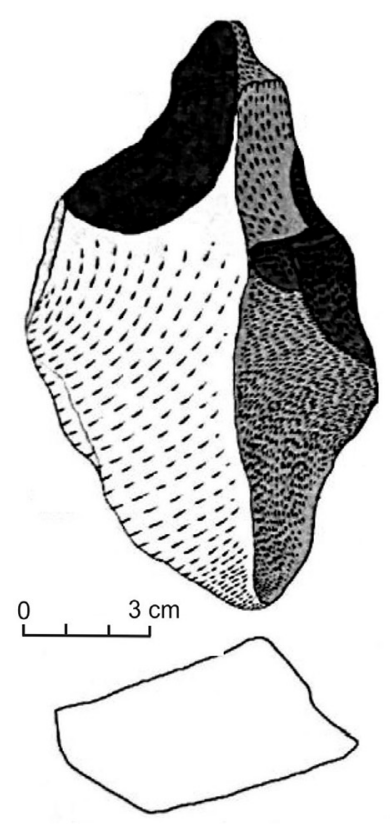

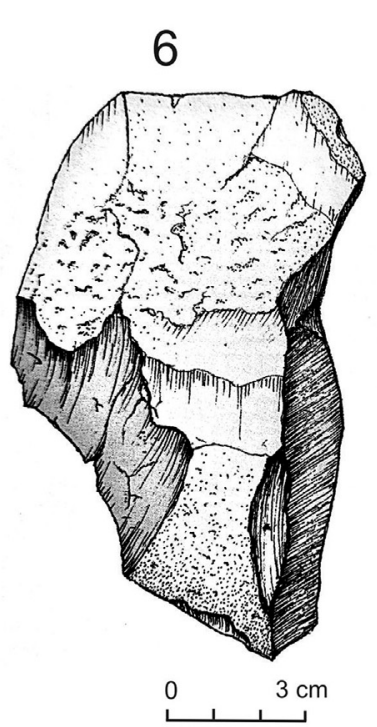

7
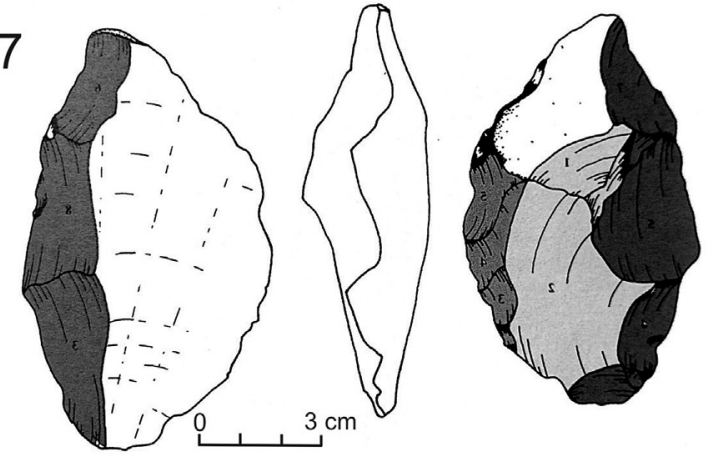

8

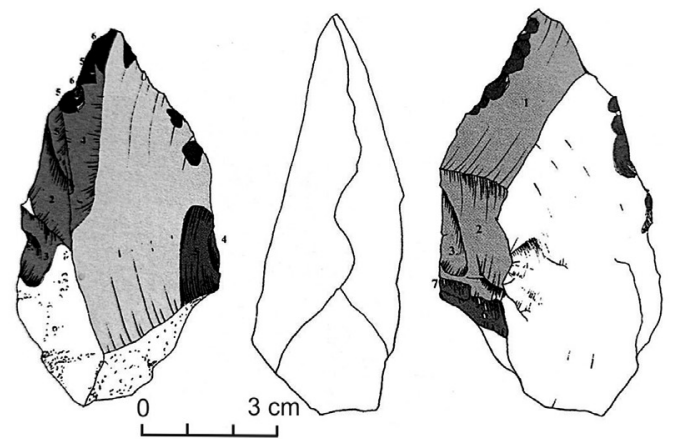

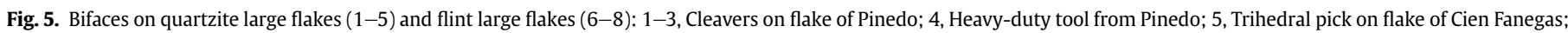

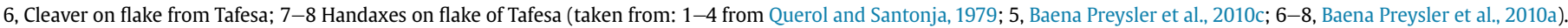

dominant. Finally, the choppers, which are hardly distinguished from the cores (Baena Preysler et al., 2010a) were made through opposite removals that form pointed edges.

Downstream from Talavera de la Reina, in the $T+30 \mathrm{~m}$, several Acheulean assemblages have been identified. Nearly 30 pieces were found in Dehesa de Cobisa (Calera y Chozas), including unretouched flakes, five cores, several trihedral picks, one chopper and a partial handaxe (Rodríguez de Tembleque, 2008). In Peraleda de la Mata and in the surroundings of Puente de Los Mármoles, some Levallois pieces, handaxes and cleavers on flake have been recorded 
(Santonja, 1981a; Santonja and Pérez-González, 2000-2001). In La Casa del Guarda, at the $\mathrm{T}+30 \mathrm{~m}$ of the stream Lientes-Valgrande (tributary of the River Tagus on its left bank), faunal remains have been recorded within a low overbank deposit. Additionally, 12 fresh pieces of flint and quartzite with sharp edges, débitage -some of which can be refitted- and a unifacially knapped chopper were recovered (Rodríguez de Tembleque et al., 2007-2008).

Finally, in Miradero de Porquillas (San Bartolomé de las Abiertas), located at the terrace $+26 \mathrm{~m}$ of the River Sangrera, affluent of the River Tagus, a plentiful industrial assemblage was found. This consisted mainly of quartzite pieces, from which the handaxes are outstanding (Rodríguez de Tembleque, 2008).

In the valley of the River Jarama, the Arganda I lithostratigraphic unit in the CTA is equivalent to the $\mathrm{T}+30-32 \mathrm{~m}$ (Pérez-González and Uribelarrea, 2002; Panera et al., 2011). In Arganda I a significant number of lithic tools have been retrieved from channel bars. Two sites in floodplain facies have been excavated, Áridos 1 and Áridos 2. With regard to the lithic tools, among the chaînes operatoires of débitage, the low representation of discoids and the prevalence of less elaborate exploitation schemes such as unipolar and bifacial schemes is remarkable. The high presence of cortex in the quartzite flakes suggests a predominance of short lithic chaînes operatoires, typical of unipolar exploitation schemes. The tools on flake, among which no complex types have been recorded, show single retouch types. The flint flakes are slightly more retouched than those from quartzite, just as occurs at bifaces. The chaînes operatoire of façonnage, are dominated by choppers, followed by handaxes and trihedral picks, and to a lesser extent by cleavers on flake. More than half of the handaxes are partial, most of them knapped on a flake, and the remaining show amygdaloid silhouettes. The bifaces on flint flake, which are probably imported, are larger in size than those made from quartzite. The trihedral picks are briefly elaborated, their final shape adapted to the original nodule, just like the cleavers on flake, which are of the 0 and I types.

Two paleo-surfaces were distinguished in Áridos 1, where $112 \mathrm{~m}^{2}$ were excavated (Santonja et al., 1980). In the lower surface, 328 lithic pieces were found associated with the disarticulated and incomplete remains of one single specimen of E. (Paleoloxodon) antiquus. The site was interpreted as a butchering site. Nearly three quarters of the lithic assemblage consists of debris and fragments, mainly flint, and the rest are flakes, tools and macrotools, suggesting that part of the industry was knapped in situ. Most pieces are flint, only $4 \%$ quartzite and just $1 \%$ quartz. Hammerstones and choppers were made of quartzite, whilst nearly all the retouched tools were made of flint, as well as the cores -except for one very large example- and handaxes. There are two Levallois cores and six Levallois flakes. Among the retouched tools, the lack of scrapers and notches is outstanding, as well as the high number of burins showing traces of having been sharpened on different occasions. The handaxes are represented only by two distal fragments, and several flakes of resharpening, which suggest that these tools were introduced already manufactured and were resharpened on site (Santonja et al., 1980).

$200 \mathrm{~m}$ from Áridos 1, the remains of E. (Paleoloxodon) antiquus were found together with 34 lithic pieces at Áridos 2 (Santonja and Querol, 1980). The central portion of the skeleton was found anatomically connected in the preserved $12 \mathrm{~m}^{2}$ of the site. The remains were lying over an old floodplain surface, covered and partially eroded by gravel and sand deposits. The relationship between the industry and the elephant is not as clear as in Áridos 1 , although cut marks have been recorded on some bone surfaces (Yravedra et al., 2010), as well as wear traces on some lithic pieces (Ollé, 2005). The industry is mainly made of flint, except for two flakes and the macrotools of quartzite. Nearly half of the pieces are débitage and fragments, suggesting that at least part of the flint was knapped there, although the chaînes operatoires are not complete. There are no Levallois among the flakes and only a few are retouched. The bifaces consist of a handaxe with lanceolate ficron silhouette, and a cleaver on flake similar to Tixier's II type. The lack of flakes and débitage suggests that these pieces had probably arrived on site already configured.

In the San Isidro hill, in Madrid, located in the T $+25-30 \mathrm{~m}$ of the Manzanares valley, discoveries of E. (Paleoloxodon) antiquus with faunal associations belonging to the Middle Pleistocene (Sese and Soto, 2002), and Acheulean industry have been unearthed since the middle of the 19th century. As is usual in the Manzanares valley, the industry is mainly made of flint. The only available detailed study is the one carried out on 191 handaxes (Santonja, 1977), in which two assemblages were distinguished; one consisting of thick amygdaloids, relatively symmetrical, and the other consisting of better made handaxes, retouched with soft hammerstone, among which the cordiform, lanceolate and ovoid types were frequent (Santonja, 1977). Recently a flint trihedral pick and a quartz chopping-tool have been recorded on this hill, as well as a unipolar core on quartz flake, an un-retouched flake and a fragment of a quartzite tool (Gómez Hernánz et al., 2005).

In the Transfesa site, located in the same terrace $7 \mathrm{~km}$ downstream from San Isidro, remains of two male adults of Elephas $(P)$ antiquus were recorded in the 1950's (Meléndez and Aguirre, 1958). These remains were lying on a level of fluvial gravels covered by associated gravel and marl, which probably would have formed part of an abandoned meander (Santonja et al., 2001). Remains of suidae, cervidae and equines were also found. In this same level (Quero Castro, 2002) the presence of lithic industry has been noted (Andres and Aguirre, 1974), although it is not possible to establish a relationship between the lithic tools and the faunal remains. A total 163 lithic pieces come from the basal gravel (Cacho and Martos, 2002). Among these, there are plenty of thick asymmetrical handaxes, of abbevillian and amygdaloid types, as well as retouched flakes and amorphous cores (Rus, 1989).

In 1996 a new site, named Tafesa, was excavated close to that site (Baena Preysler and Baquedano, 2004; Baena Preysler et al., 2010a). Silva et al. (2010) locate the site in what they call TCMZ (T9) o $\mathrm{T}+22 \mathrm{~m}$ of the River Manzanares, even though it has traditionally been assigned to the stepped terrace $+25-30 \mathrm{~m}$ (Goy et al., 1989), as can be inferred looking at the topography of the valley. The lithic assemblage of this site can be compared to those recorded from sites at the middle terraces of the River Tagus, located $+25-30 \mathrm{~m}$ from Pinedo or Cien Fanegas. An area $100 \mathrm{~m}^{2}$ was excavated on an old floodplain crossed by drainage channels (Silva et al., 1997). Remains of Elephas (P) antiquus, Bos, mid-sized deers, Megaloceros savini, and Oryctolagus cuniculus were recorded (Sese, 2010), together with 651 lithic pieces arranged in four levels. 464 of those pieces were recovered from level IV, in an area only $30 \mathrm{~m}^{2}$ (Baena Preysler and Baquedano, 2004; Baena Preysler et al., 2010a). With regard to the lithic industry, there is a minor use of quartzite and quartz versus flint. The use of old industries as blanks has been recorded in the configuration of both macrotools and cores. The high presence of cobbles is remarkable (36\%), although only six of them show percussion marks (Baena Preysler et al., 2010a; Cuartero, 2010). Macro tools, which consist almost $20 \%$ of the total, are also well represented, as well as other tools, which reach values higher than $30 \%$. The flake production is focused mainly on bifacial and multifacial operative schemes, and to a lesser extent on orthogonal and discoid schemes, with no presence of Levallois (Baena Preysler et al., 2010a), suggesting an expeditious assemblage. Among the tools on flake denticulates are dominant, followed by scrapers, notches and becs (Baena Preysler et al., 2010a). There are no choppers among the macro tools. There are only two cleavers on flake, in contrast with the 22 
handaxes and trihedral-picks present, which are thick, with sinuous edges and barely symmetrical profiles (Fig. 5). The presence of débitage, hammerstones and some refits suggests the knapping was carried out on site.

\subsubsection{Terrace $+23-24 m$}

Only data from the Jarama valley are available for this terrace level. In Las Acacias 114 pieces were retrieved from near the base of a section where fragments of Elephas tusks were recorded (Santonja and Querol, 1977). The raw material is mainly quartzite, and in a very low proportion, flint. The unifacial and bifacial types dominate among the cores, and there is one similar to a Levallois. The most common tools on flake are scrapers, which show deep and regular retouch (Santonja, 1981a), followed by natural backed knives and Mousterian points. Macro tools represent more than one third of the assemblage, including plentiful choppers, handaxes and cleavers on flake, whereas trihedral picks are barely represented. Both flat and thick handaxes are equally present, the cordiform, amygdaloid and protolimande silhouettes being notable. Among the cleavers on flake, those made on an ordinary flake or II type are dominant, followed by the 0 type, with generally sinuous edges.

The site of Valdocarros, where the largest extension of an Acheulean site has ever been excavated in the Iberian Peninsula after Torralba and Ambrona, is located to the upper third of the Arganda II stratigraphical unit $(\approx \mathrm{T}+23-24 \mathrm{~m})$. Three sedimentary episodes have been recorded, which have been named, from bottom to top, I, II and III. Valdocarros I and III consist of wide floodplains away from the main course. Valdocarros II consists of an abandoned meander integrating two different sedimentary environments; one towards the bottom, with gravel deposits and sand in channel facies eroding Valdocarros I, and another one consisting of a silty-clay and sand fill in which four levels $30-50 \mathrm{~cm}$ thick containing lithic industry and faunal remains have been distinguished. In Valdocarros I, $18 \mathrm{~m}^{2}$ have been excavated, and $836 \mathrm{~m}^{2}$ in Valdocarros II (Fig. 6). The association of reptiles and amphibians recorded in levels 2, 3 and 4 of Valdocarros II suggests a quick climatic shift. This could be matched with the transition between MIS
8 and MIS 7 (Blain et al., 2012). The faunal remains are fragmented, disarticulated and show a similar distribution to that of the lithic industry. Among the 2750 remains of large mammals retrieved, Cervus elaphus is the best represented species, followed by Equus caballus, Bos primigenius and to a lesser extent Capreolus sp., Dama sp., and Elephas sp. (Yravedra and Domínguez-Rodrigo, 2009). A small amount of carnivorous remains must be added to this assemblage (Felix sp., Canis lupus and Vulpes vulpes). Nearly two thirds of the lithic assemblage consists of flint pieces, a third of quartzite and the rest is quartz. Flint is mainly used for flake production, whilst quartzite is used for both flakes and macrotools. Scarcely elaborated quartzite cores predominate within the identified operative schemes (unifacial, bifacial, and to a lesser extent, jano), as opposed to discoids. The bifacial, multifacial and discoid types dominate among the flint cores. Only one Levallois core has been recorded, although several flakes have been obtained by this method. The retouched tools have been knapped mainly on flint, whether on flakes, cores or even old industries. The best represented morphotypes are denticulates, retouched flakes, scrapers and backed knives. Awls and burins have also been recorded. Most of bifaces are handaxes, followed by cleavers on flake, whilst trihedral picks are barely represented. Most handaxes have been made from quartzite, and some from flint (Figs. 7 and 8). Many of them have been adapted to the shape of the support, showing few removals, especially in the case of flakes and old industries used as blanks. All cleavers on flake are quartzite and 0 or 1 types, characterised by the edges being arranged with only few removals (Fig. 8). Most choppers are quartzite, some flint and quartz in one case, showing unifacial simple edges, and to a lesser extent simple and double bifacial edges.

\subsubsection{Complex Terrace of Butarque (CTB)}

Several Acheulean lithic assemblages have been found at the visible base of the initial trench of this terrace, which can reach up to $70 \mathrm{~m}$ in thickness (Uribelarrea, 2008). The chronological data can only point to its position within the Middle Pleistocene (Laplana et al., 2015), as it is not possible to specify whether it falls in MIS 7 or MIS 6.

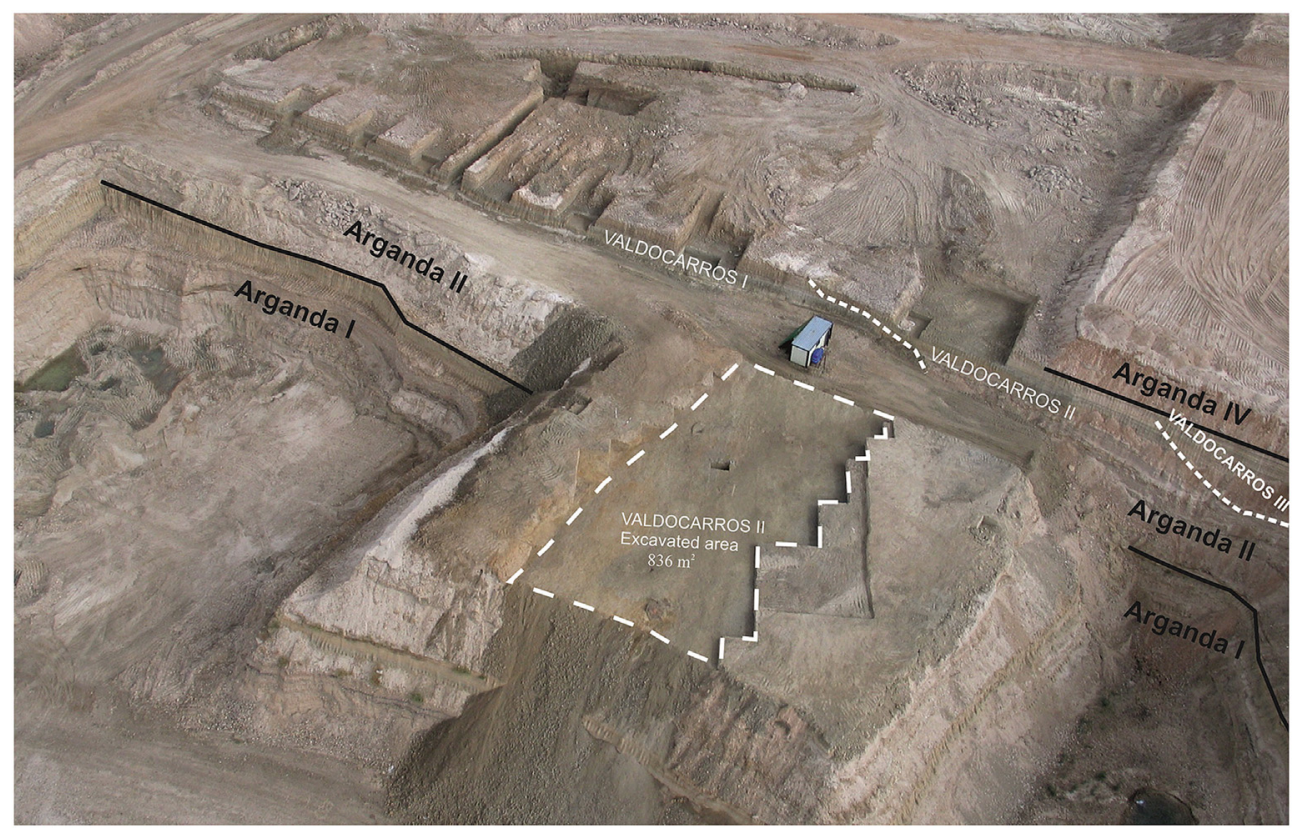

Fig. 6. Aerial view of Valdocarros site (Madrid, Spain). 


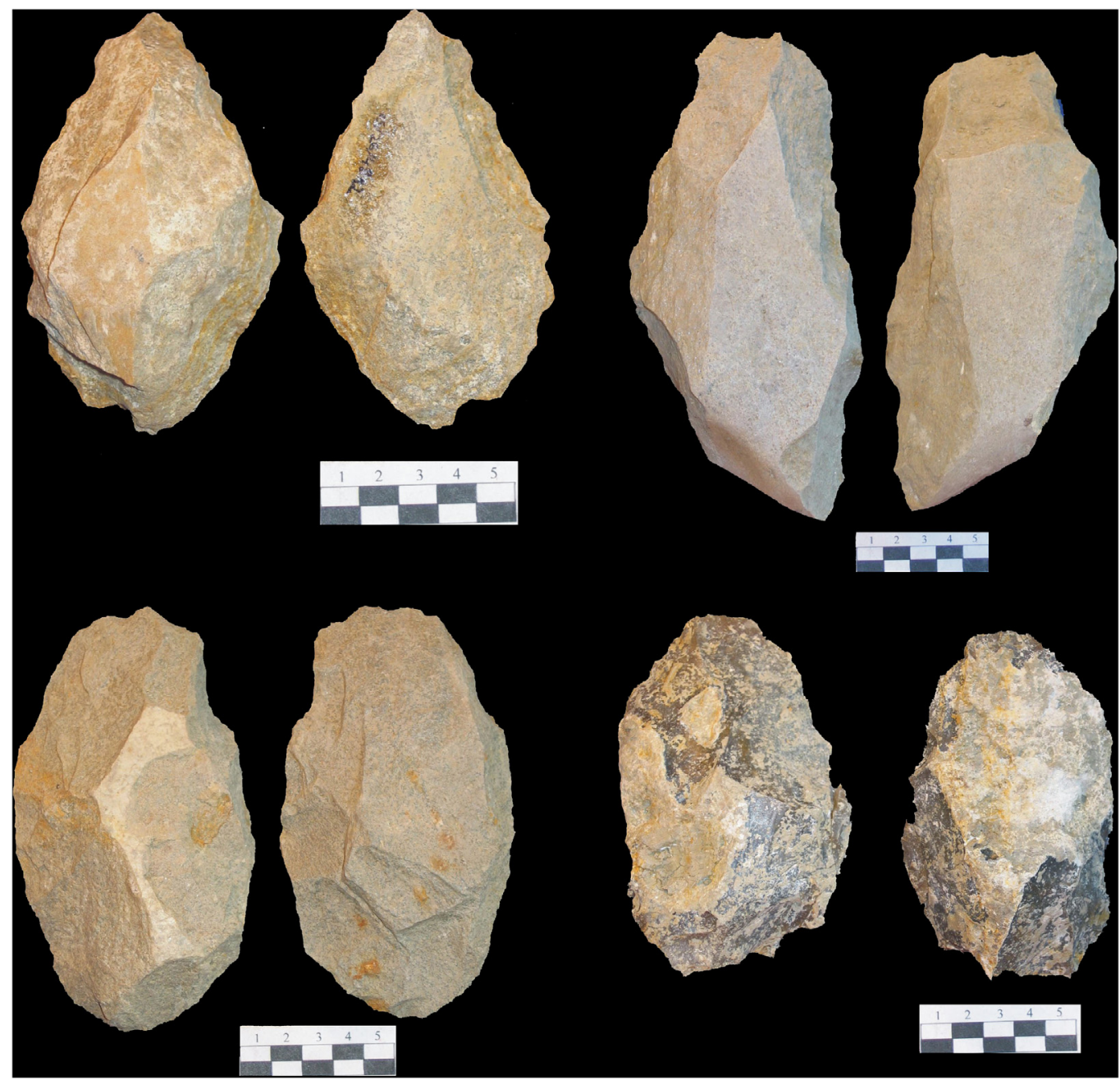

Fig. 7. Handaxes on quarzite and flint from Valdocarros II site (Madrid, Spain).

A total of 4921 pieces were found at the Santa Elena sand quarry (Cacho and Martos, 2002; Gamazo, 2002), matching different units within the CTB, which were comprised since the final Middle Pleistocene to the early Upper Pleistocene. Acheulean and Middle Palaeolithic industries have been recorded, although the levels have not been distinguished so far. Bifaces are well represented in this assemblage, together with a substantial number of Levallois cores and a certain percentage of tools on blades, which are probably related to Upper Pleistocene deposits. Among the handaxes, lanceolate and micoquian specimens are plentiful. Trihedral picks show slender silhouettes, and those made on kombewa flake, Levallois and Tixier's $\mathrm{V}$ type stand out among the cleavers on flake (Santonja and Querol, 1980). The faunal association of this sand quarry can be put down to the Middle Pleistocene, and comprises Elephas $(P)$ antiquus, Rhinocerotidae indet., Equus caballus, Cervidae indet., Bovidae indet. cf. Bos/Bison (Sese and Soto, 2002).

A further faunal assemblage dated in the Middle Pleistocene was recorded at the Oxígeno sand quarry (Elephas $(P)$ antiquus, Equus caballus, Cervidae indet., Bovidae indet. cf. Bos/Bison) (Sese and Soto, 2002: 448), where 10,416 lithic pieces were retrieved (Cacho and Martos, 2002; Gamazo, 2002). Within a series of 5000 pieces, mainly flakes and fragments, 219 handaxes were recovered, as well as 38 trihedral picks and 21 cleavers. Most of them are made of flint, and a few of quartzite (Rus and Querol, 1981). Most handaxes are made on flake. The thick ones are dominant (195), and include lanceolate-micoquian types, as well as amygdaloid and protolimandes; among the flat handaxes, cordiform, discoid and ovoid types stand out. The edges have been regularised or sharpened with a soft hammerstone. The best represented cleavers are of Tixier's V, II, 0 and I types (1956), showing regular symmetric silhouettes, usually shaped with a hard hammerstone, which is also used for making trihedral picks, mainly on flake.

\subsubsection{Interfluve between the Manzanares and Jarama rivers}

The sites recorded at Los Ahijones are found on the dividing platform along the Manzanares-Jarama rivers valleys (Figs. 1 and 2 ). This is characterised by the presence of layers of flint and carbonated clay belonging to the Middle Miocene, which forms the headwaters of the main drainage net of the platform, consisting of Los Migueles stream (affluent of the River Manzanares), and its tributaries, Los Ahijones and El Cañaveral stream (Bárez et al., 2010). The sites recorded in this area are related to the primary outcrops of siliceous rocks, and to its reiterate use as source of raw materials (Baena Preysler et al., 2015). In terraces T1, T2 and T3 of Cañaveral, dated in the final Middle Pleistocene (T1 > $150 \mathrm{ka}$ BP and $115+32 /-19$ ka BP for the edaphic horizon developed over T2, Bárez et al., 2010), nine Acheulean lithic assemblages have been found. There is a high percentage of handaxes, although cleavers on flake and trihedral picks are virtually absent. 

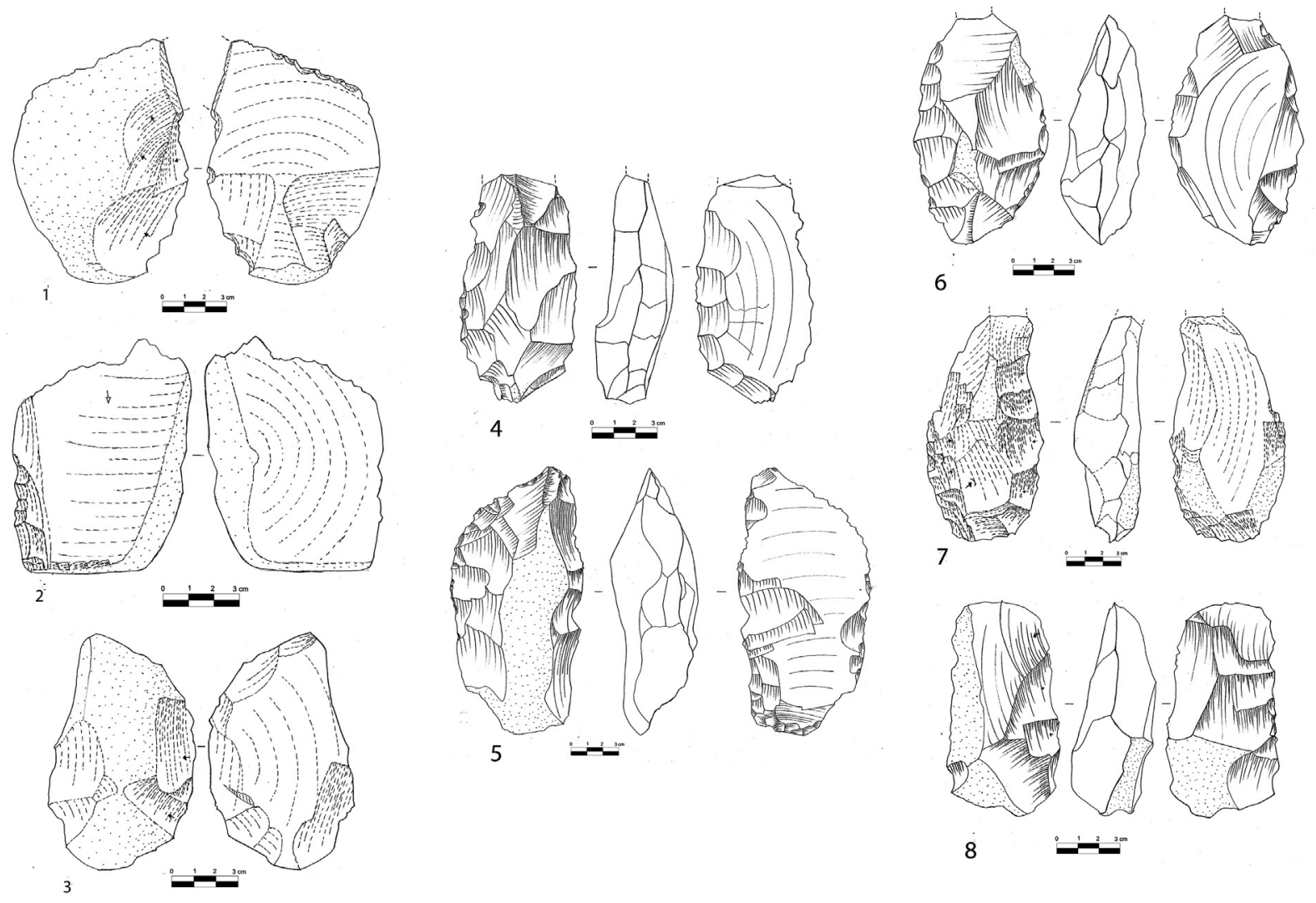

8

Fig. 8. Valdocarros II site (Madrid, Spain). 1-3. Cleavers on flake. 4-7. Handaxes on flake. 8. Cleaver.

The site of El Cañaveral (Baena Preysler et al., 2008a, 2008b, 2010b), has also been linked to the direct exploitation of siliceous outcrops, which favoured its exploitation during the Pleistocene, having been recorded in the same environment Acheulean and Mousterian lithic assemblages (Baena Preysler et al., 2008a,b). Several sub-categories concerning the exploitation of recycled material have been distinguished: old industries have been exploited, retouched or used as hammerstones, having used cores as hammerstones or vice versa (Baena Presyaler et al., 2011, 2015).

\section{Discussion}

In the Tagus basin, the first evidence of the Acheulean technocomplex can be dated to the MIS 15-12 and certainly to MIS 11. If the Acheulean period entered Europe through the Strait of Gibraltar (Santonja and Villa, 2006; Santonja and Pérez-González, 2010; Moncel et al., in press), the Tagus basin necessarily had to play an important role in its extension throughout Southern Europe. The valley of the river Tagus, along its $1007 \mathrm{~km}$, connects the south of the Iberian Peninsula with the other two large basins of the Iberian Peninsula, the Duero and the Ebro basins.

No site has been excavated in the Tagus basin with a date prior to MIS 13. The small number of lithic finds referable to this period are located in the middle and high terraces of the Tagus valley and in some of its tributaries. In this valley, in the $T+105 \mathrm{~m}$ and $\mathrm{T}$ $+83 \mathrm{~m}$, there is evidence of human presence with dates older than one million years. This comes from a relative date of the terrace deposit in which poor assemblages of lithic industry have been found, with no diagnostic specimens which would allow them to be assigned to a particular techno-complex (Santonja and Pérez-González, 1997; Rodríguez de Tembleque et al., 2010). In the River Arlanzón valley, in the Duero basin, the terrace $+70-78 \mathrm{~m}$ with normal polarity (Benito-Calvo et al., 2008), and dated by ESR to 1.140 Ma (Moreno et al., 2012), may represent the normal Subchron Jaramillo (0.990-1.070 Ma; Pérez-González et al., 2013).

The oldest evidence of the Acheulean occurs in a terrace located at $70 \mathrm{~m}$ relative height, where a biface on flake was found. This could date the beginning of this techno-complex to the end of the Lower Pleistocene, although new discoveries of greater importance may well take place. The evidence is more solid in $\mathrm{T}+40-45 \mathrm{~m}$ at Hornaguera and Paridera, (Santonja and Pérez-González, 1997; Rodríguez de Tembleque, 2008). These terrace levels may correspond with MIS 15-12, considering that terrace $+50-55 \mathrm{~m}$ (Panera et al., 2011) could be as old as 0.7-0.6 Ma according to the ESR dates of this terrace level at the Arlanzón valley, in the Duero basin (Moreno et al., 2012), and the date $292 \pm 17 \mathrm{ka}$, obtained by IRSL in the $\mathrm{T}+25-30 \mathrm{~m}$ of the Tagus valley (López-Recio et al., 2015).

Puente Pino could be the oldest Acheulean site excavated in the Tagus basin, taking into consideration that PNA could fill an intermediate position between the terraces $+40-45 \mathrm{~m}$ and $+30 \mathrm{~m}$ of the regional fluvial sequence of the River Tagus (Rodríguez de Tembleque, 2004, 2005a, 2008).

Acheulean lithic assemblages become common from level $+30 \mathrm{~m}$, as has been revealed in the unit Arganda $\mathrm{I} \approx \mathrm{T}+30-32 \mathrm{~m}$ of the Jarama valley, and the $\mathrm{T}+25-30 \mathrm{~m}$ of the Tagus and Manzanares valleys. From this moment on, Acheulean assemblages have been recorded in the valleys of the main and secondary rivers of the Tagus basin. The $\mathrm{T}+25 \mathrm{~m}$ has been dated to the MIS 11-13 (Sese and Soto, 2000; Mazo, 2010), Arganda I to the end of MIS 11 or early MIS 9 (Panera et al., 2011), and the T $+25-30 \mathrm{~m}$ of the Tagus valley to the final MIS 9 or early MIS 8 (López-Recio et al., 2015). 
Valdocarros, in the unit Arganda II of the CTA $(\approx T+23-24 \mathrm{~m})$, is the excavated Acheulean site which provides a late date, between MIS 8 and MIS 7 (Panera et al., 2011; Blain et al., 2012). Lithic industry assemblages have also been recorded in secondary positions in the Arganda II gravel bars.

The latest evidence of the Acheulean technocomplex in the Tagus basin could be located at the $\mathrm{T}+18-20 \mathrm{~m}$ and in the visible base of the CTB initial stretch, in the Manzanares valley, which date to the final Middle Pleistocene (Laplana et al., 2015). The materials ascribed to the Acheulean found in the Manzanares and Jarama interfluve have also been ascribed to this time (Bárez et al., 2010; Baena Preysler et al., 2015).

Fluvial loads have been influential in the choice of raw materials used for manufacturing lithic tools, but not decisive. Thus, in the Tagus and Jarama valleys, where there is plenty of quartzite, the châines opératoires of façonnage, particularly those set aside for production of choppers and cleavers, are better represented than in the Manzanares valley, where flint predominates and quartzite is absent. Nevertheless in this valley manufacturing of bifaces on flake is frequent. Then again, in the in situ sites of the Jarama valley, flint pieces are frequent in the châines opératoires of débitage, despite being a rare raw material. This could be interpreted as the requirements of the functionality of the site, or else flint was preferred for knapping tools on smaller flakes.

There is little information about some levels of terraces, particularly the highest and the lowest. Besides, this information often comes from old research and publications, making it difficult to elicit general conclusions.

With regard to macro tools, handaxes, often knapped on large flakes, are the most frequently recorded tools, followed by choppers, while cleavers and trihedral-trihedral picks are less represented. Among the handaxes, thick, asymmetrical, rough types are dominant, with irregular edges and barely retouched. Nevertheless, more carefully elaborated and balanced specimens are also found, such as those from San Isidro and Las Acacias (Santonja, 1977; Santonja and Querol, 1977). The most frequent cleavers on flake are of Tixier's type 0 and, to a lesser extent, type 1 (Tixier Inizan, 1956). With regard to the cores, the predominant châines opératoires are bifacial and polyhedral, followed by discoid, which are normally well represented. Levallois cores are exceptional. The most common retouched tools on flake are scrapers, followed by denticulates. More elaborated types such as awls and, particularly, end-scrapers, are scarce.

The main source of information for the characterization of the lithic industry of the final Middle Pleistocene is the Manzanares valley, specifically from $\mathrm{T}+18-20 \mathrm{~m}$ and from the visible bottom of the CTB, and also old research of poorly published lithic assemblages. Flint is the predominant raw material due to the lack of quartzite in the load of this river. These deposits contain the last clearly Acheulean evidence. The châines opératoires of façonnage, with meagre percentages, are almost exclusively represented by handaxes and to a lesser extent by cleavers on flake and trihedral picks, choppers being totally absent. Handaxes continue being manufactured frequently on large flakes, although thick ones are still predominant. Their silhouettes tend to be well balanced and symmetrical, and the edges regularized or resharpened by retouch, although poorly elaborated edges are also present. As for the cleavers, regular silhouettes are also common. Tixier's types $\mathrm{V}$ and II are predominant, followed by types 0 and I. Flakes have not usually been detached from the cores in a preconceived manner. Discoid types are not always present, and when they are, it is in low percentages. The most common cores are non-organized and with a low number of removals. With regard to the retouched tools, scrapers and denticulates are predominant, although all types described by Bordes (1961) are present.
The basic differences between the lithic assemblages recorded on the one hand in the terraces $+30 \mathrm{~m}$ and $+23-24 \mathrm{~m}$, and on the other hand in the terrace $+18-20 \mathrm{~m}$, lie, above all, in the configuration of the châines opératoires of façonnage, particularly in the case of the handaxes, as choppers have hardly been described, and the percentage of cleavers on flake and trihedral picks is inferior in the lower terrace. Higher percentages of well-made handaxes, well balanced and symmetrical, with edges regularized or resharpened by retouch have been recorded in this level. Cleavers on flake show regular silhouettes, and Tixier's types V and II are predominant. A certain rise of the complex types can be observed among the retouched tools, although scrapers and denticulates continue to dominate the sample. However, clear differences cannot be established in the châines opératoires of débitage. The most common cores are elemental and without an organized exploitation scheme. Discoids cores are uncommon, and Levallois cores are scarce.

The Acheulean assemblages found in the interfluve between the Manzanares and Jarama rivers, associated with primary flint outcrops, are characterized by a high percentage of handaxes, and an almost total lack of cleavers and trihedral picks (Baena Preysler et al., 2008a,b; Bárez et al., 2010).

In the Iberian Peninsula, the Middle Palaeolithic has been recorded since MIS 10/9 in sites such as Ambrona, Cuesta de la Bajada or TD 10 in Atapuerca (Rubio-Jara, 1996; Santonja and PérezGonzález, 2006; Ollé et al., 2013; Santonja et al., 2014), coexisting with Acheulean sites, such as Torralba and Valdocarros (Santonja et al., in press). There is conspicuous evidence of the Middle Palaeolithic during MIS 5 in the Jarama and Manzanares valleys (Panera et al., 2005; Pérez-González et al., 2008), and even probably since the final Middle Pleistocene, although the timeframe cannot be accurately specified (Panera, 2009; Rubio-Jara, 2011). In the Manzanares valley and in the interfluve between this and the Jarama river, lithic assemblages with a practical dearth of cleavers on flake, trihedral picks and choppers are recorded, containing bifaces-tool support (Boëda, 2001), and with a stronger Levallois presence (Bárez et al., 2010; Rubio-Jara, 2011; Baena Preysler et al., 2015). This could be the result of the relation between the Acheulean and EAMP, as pointed out by Santonja et al. (in press). More accurate timeframes and detailed techno-economic descriptions of these lithic assemblages are necessary for their understanding and characterization.

Many Acheulean lithic assemblages have been found in gravel or sand bars (Pinedo, Cañete, La Gavia I, Santa Elena, Oxígeno). As a result, the remains have been moved from their original location and may come from other spots where different activities were carried out. This type of site provides techno-economic information, whereas sites found on overbank facies (Áridos 1 y 2, San Isidro, Valdocarros, Transfesa and Tafesa), have optimal preservation of the spatial relationship of the remains, and also provide information regarding how the human groups adapted to the fluvial ecosystems.

Several sites with remains of $E$. (Paleoloxodon) antiquus associated with lithic industry are known in the terrace $+25-30 \mathrm{~m}$ (San Isidro, Orcasitas, Transfesa and Áridos 1 y 2; Santonja et al., 2001), although they are old findings, incompletely recorded, except for Áridos 1 and 2. Remains of proboscidea dating between MIS 6 and MIS 5 have been recorded in 17 sand quarries at the CTB in the Manzanares valley, and in at least four cases interaction between hominins and megafauna were proven (Panera et al., 2014). There are more Lower Paleolithic sites than Middle Palaeolithic known in Europe, where exploitation of proboscideans has been proved. However, the findings recorded from the Manzanares valley reveal that there were no important changes in the subsistance strategies with regard to these mammals during the Acheulean and the Middle Paleolithic. 
The sector PNA of Puente Pino has been interpreted as a site where human groups manufactured and used lithic tools in unspecific activities, based on the presence of complete lithic châines opératoires, and the concentration and diversity of industry and tools (Rodríguez de Tembleque, 2008). The strategic location of the site, the record of different archaeological levels and the presence of several Acheulean sites in the surroundings suggest that the area was recurrently visited by human groups (Ruiz Zapata et al., 2009).

In Tafesa (Baena Preysler and Baquedano, 2004), presence of knapping remains, hammerstones and some refits suggests knapping being carried out on site. According to cut marks identified on diaphysis of large mammals, knapping would be related, at least in part, to meat consumption (Yravedra, 2010).

The site that gives more information about the interaction between human groups and the environment is Valdocarros. The abandoned meander of Valdocarros II was occupied at least on four different occasions and under different climatic conditions. The human groups went back several times, probably attracted by the proximity to a substantial river, the shelter provided by the meander depression and the dense vegetation. The hominins were the main agent of accumulation of vertebrate remains, moving the carcasses from short distances (Yravedra and Domínguez-Rodrigo, 2009). In Valdocarros II, knapping has been related mainly with core reduction, and in some levels with handaxe shaping and resharpening. Most sites excavated in the Iberian Peninsula to date correspond to specific activities, such as exploitation of large mammal carcasses or knapping lithic tools. Valdocarros, which presents one of the largest areas with Pleistocene archaeological remains of the Iberian Peninsula, is a different case.

With regard to raw material collection, the Jarama and Tagus valleys have yielded plenty of quartzite and quartz cobbles, whereas the primary flint outcrops from the Manzanares-Jarama interfluve have been recurrently exploited since the final Middle Pleistocene (Bárez et al., 2010; Baena Preysler et al., 2015).

Acheulean sites with middle to high industrial density have also been described from deposits developed on high terraces, $+50 \mathrm{~m}$ or more, as well as middle ones, sometimes on alluvial fans (Rodríguez de Tembleque, 1997; Panera, 2009). Despite lacking a timeframe, these lithic assemblages allow the exploration of the spatial frame of the Acheulean groups, beyond the activities carried out on the floodplains (Díez-Martín et al., 2008).

\section{Conclusions}

Practically all the Acheulean sites have been recorded in fluvial terraces, which has limited all the available information to this sedimentary environment. This is due to the ability of this environment to generate and preserve deposits, plus the subsistence potential which characterises Mediterranean fluvial valley ecosystems, which constituted authentic ecological corridors, making the faunal circulation between different geographic areas and ecosystems easier. Other morphosedimentary environments present in the basin, such as karstic, have not been subject of systematic research, and could yet give relevant information on the topic.

Despite lacking an accurate timeframe, the first Acheulean evidence could be dated to between MIS 15 and 13. In accordance with the numerous lithic assemblages found in stratigraphical contexts and by the sites excavated in $\mathrm{T} \approx+30 \mathrm{~m}$, from MIS 11 on, at most MIS 9, this techno-complex is widely spread throughout the Tagus basin. Valdocarros ( $\approx \mathrm{T}+23-24 \mathrm{~m}$ ), ascribed to MIS 8/7, is the most recent Acheulean site excavated in the Tagus basin, and one of the most recent of the Iberian Peninsula. The final Acheulean evidence could be dated to MIS 6, in the T $+18-20 \mathrm{~m}$ and in the visible bottom at the initial stretch of the CTB at the Manzanares valley.
As in the case of the African Acheulean, and the rest of the Iberian Peninsula and Southern France, the châines opératoires of façonnage are present in significant percentages, and the use of large flakes for shaping bifaces is common, although the available raw materials have an influence on their representativeness. Handaxes, often made on flake, are the most common bifaces. They tend to be poorly elaborated, with non-regularized or nonretouched edges. Trihedral picks are scarcely represented, and cleavers on flake are of 0 and 1Tixier's types. With regard to the châines opératoires of débitage, short examples predominate in quartzite, and polyhedral and discoid in flint. Levallois presence is scarce. As observed from sites on overbank facies, there is a certain preference for flint for knapping small tools. Retouched tools are usually little elaborated. Scrapers and denticulates are the most characteristic morphotypes.

To the end of the Middle Pleistocene, in the Manzanares valley and in the interfluve with the River Jarama, lithic assemblages with châines opératoires of façonnage are present in the archaeological record, almost exclusively represented by handaxes. These handaxes are more elaborate than previous and their edges have been regularized by retouch. Cleavers on flake of Tixier's V and II types are also included in these assemblages, as well as complex retouched tools on flake. Levallois cores are also present. These assemblages may respond to the interrelation between Acheulean and EAMP suggested by Santonja et al. (in press).

With regard to the adaptation of the human groups with Acheulean technology to fluvial ecosystems, the number of sites where proboscidean remains have been found associated with lithic industry is outstanding. This is also recorded during the Middle Palaeolithic, unlike in other European regions, and should be analysed under the relations which occurred between these techno-complexes. In other sites, such as Puente Pino or Tafesa, we do not know the activities carried out by the hominins, beyond manufacturing lithic tools. Evidence from Valdocarros has shown for the first time an occupation site where human groups went at different occasions and under different climatic conditions; where lithic tools were brought, as well as raw materials for manufacturing new ones; and where parts of large mammals carcasses were exploited using these tools. The activities of human groups with Acheulean technology were developed beyond the floodplains, according to the lithic assemblages found on the middle terraces, higher than $+50 \mathrm{~m}$, and by the primary flint outcrops in the Jarama-Manzanares interfluve, which have been recurrently exploited since the end of the Middle Pleistocene.

\section{Acknowledgements}

We would like to express our gratitude to the editors for inviting us to participate in this special issue; to the Dirección General de Patrimonio Histórico de la Comunidad de Madrid and Diputación de Toledo for financing the excavation works at Valdocarros and Puente Pino sites; and to Marta Muñiz and Ciara Travers for English editing. We are also grateful to the two anonymous reviewers for their careful work and useful remarks.

\section{References}

Aguirre, E., 1989. Vertebrados del Pleistoceno continental. In: Pérez-González, A. Cabra, A., Martín Serrano, A. (Eds.), Mapa y Memoria del Cuaternario de España a E. 1:1.000.000. Instituto Tecnológico y Geominero de España, pp. 47-69.

Alférez, F., 1977. Estudio del sistema de terrazas del río Tajo al W de Toledo. Estudios Geológicos 33, 223-250.

Alférez, F., 1978. Presencia de Eqqus stenonis Cocchi en el Pleistoceno inferior de la cuenca del Tajo. Estudios Geológicos 34, 553-558.

Alférez, F., 1999. Algunos aspectos geológicos y paleontológicos del sistema de terrazas de Tajo al oeste de Toledo. In: La huella del pasado: Fósiles de Castilla- 
La Mancha. Patrimonio Histórico-Arqueología de Castilla-La Mancha (Junta de Comunidades de Castilla la Mancha, (Ed), pp. 307-326.

Alia, M., 1960. Sobre la tectónica profunda de la fosa del Tajo. Notas y Comunicaciones del Instituto Tecnológico y Geominero de España 58, 125-162.

Andres, I., Aguirre, E., 1974. Un molde endocraneano de Praedama (cérvido) del Pleistoceno Medio de Madrid. Quaternaria 18, 303-330.

Baena Preysler, J., Baquedano, I., 2004. Avance de los trabajos arqueológicos realizados en el yacimiento paleolítico de Tafesa, antiguo Transfesa (Villaverde, Madrid): principales rasgos tecnológicos del conjunto lítico. In: Baquedano, E. Rubio-Jara, S. (Eds.), Miscelánea en homenaje a Emiliano Aguirre, IV, Zona Arqueológica, vol. 4, pp. 31-47.

Baena Preysler, J., Bárez, S., Pérez-González, A., Lázaro, A., Nebot, A., Roca, M. Pérez, T., González, I., Cuartero, F., Rus, I., Polo, J., Márquez, R., Cabanes, i, Cruelles, D., Carrancho Alonso, A., 2008a. El yacimiento paleolítico Cañaveral (Coslada-Madrid). La captación de recursos líticos durante el Musteriense peninsular. Arqueoweb 9 (2), 1-32.

Baena Preysler, J., Polo, J., Bárez, S., Cuartero, F., Roca, M., Lázaro, A., Nebot, A., PérezGonzález, A., Pérez, T., Rus, I., Rubio, D., Martín Puig, D., Manzano, C. González, I., Márquez, R., 2008b. Tecnología musteriense en la región madrileña: un discurso enfrentado entre valles y páramos de la Meseta sur. Treballs d'Arqueología 14, 249-278.

Baena Preysler, J., Baquedano, I., Carrión, E., 2010a. La industria lítica del yacimiento paleolítico de TAFESA (Madrid). In: Baena, J., Baquedano, I. (Eds.), Las huellas de nuestro pasado. Estudio del yacimiento del Pleistoceno Madrileño de Tafesa (Antigua Transfesa), Zona Arqueológica, vol. 14, pp. 37-134.

Baena Preysler, J., Polo, J., Bárez, S., Cuartero, F., González, I., Lázaro, A., Nebot, A. Martín Puig, D., Márquez, R., Pérez-González, A., Pérez, T., Rubio, D., Roca, M. Rus, I., 2010b. El proyecto arqueológico del Cañaveral (Coslada-Madrid): gestión e investigación. Actas de las $\mathrm{V}$ jornadas de patrimonio arqueológico en la Comunidad de Madrid. Celebradas en el Museo Arqueológico Regional de la Comunidad de Madrid del 12-14 de noviembre de 2008. Alcalá de Henares, Madrid, pp. 93-114.

Baena Preysler, J., Rus, I., Cuartero, F., Martín, D., Rubio, D., Roca, M., 2010c. Estudio tecnológico de la industria lítica del yacimiento de Las Cien Fanegas (Madrid) en el contexto Achelense de la Meseta. Cuaternario y Arqueología: Homenaje a Francisco Giles Pacheco. Diputación Provincial de Cádiz, Cádiz 71-83.

Baena Preysler, J., Bárez, S., Pérez-González, A., Roca, M., Lázaro, A., Márquez, R. Rus, I., Manzano, C., Cuartero, F., Ortiz, I., Rodríguez, P., Pérez, T., González, I., Polo, J., Rubio, D., Alcaraz, M., Escobar, A., 2011. Searchers and miners: first signs of Flint exploitation in Madrid's region. In: Capota, M., Consuegra, S., Díaz del Río, P., Terradas, X. (Eds.), Proceedings of the 2nd International Conference of the UISPP Commission on Flint Mining in Pre- and Protohistoric Times (Madrid, 14-17 October 2009). BAR International Series 2260.

Baena Preysler, J., Ortiz, I., Torres, C., Bárez, S., 2015. Recycling in abundance: re-use and recycling processes in the Lower and Middle Paleolithic contexts of the central Iberian Peninsula. Quaternary International 361, 142-154.

Bar-Yosef, O., Belfer-Cohen, A., 2013. Following Pleistocene road signs of human dispersals across Eurasia. Quaternary International 285, 30-43.

Bárez, S., Rus, I., Pérez-González, A., Vega de Miguel, J., 2010. Los yacimientos achelenses de "Los Ahijones", metodología geoarqueológica y resultados preliminares de la intervención. Actas de las $\mathrm{V}$ jornadas de patrimonio arqueológico en la Comunidad de MadridCelebradas en el Museo Arqueológico Regional de la Comunidad de Madrid del 12-14 de noviembre de 2008. Alcalá de Henares, Madrid, pp. 173-189.

Barsky, D., 2013. The Caune de l'Arago stone industries in their stratigraphical context. Comptes Rendus Palevol 1, 305-325.

Barsky, D., de Lumley, H., 2010. Early European Mode 2 and the stone industry from the Caune de l'Arago's archeostratigraphical levels "P". Quaternary International 223-224, 71-86.

Benito-Calvo, A., Pérez-González, A., Parés, J.M., 2008. Quantitative reconstruction of Late Cenozoic landscapes: a case study in the Sierra de Atapuerca (Burgos, Spain). Earth Surface Processes and Landforms 33, 196-208. http://dx.doi.org/ 10.1002/esp.1534.

Blain, H.-A., Sesé, C., Panera, J., Rubio-Jara, S., Uribelarrea, D., Pérez-González, A. 2012. Paleoclimatic and paleoenvironmental proxies to the Marine Isotope Stage 7e (Middle Pleistocene) in central Spain (Valdocarros II, Madrid) by means of the small-vertebrate assemblages. In: International Conference. European Middle Palaleolithic during MIS 8-MIS 3. Cultures-environmentchronology, Wolbrom, Poland, September 25th-28th, pp. 77-78.

Boëda, E., 2001. Determination des unités tecno-fonctinelles de pièces bifaciales provenant de la couche acheuléenne C03 Base du site de Barbas I. In: Cliquet, D. (Ed.), Les industries à outils bifaciaux du Paléolithique moyen d'Europe occidentale. ERAUL 98, pp. 51-75.

Bordes, F., 1961. Typologie du Paléolithique ancien et moyen. Cahiers du Quaternaire, first ed., vol. I. du CNRS, p. 112. 2 t. (1981)

Bourguignon, L., Djema, H., Bertran, P., Lahaye, Ch, Guibert, P., 2008. Le gisementsaalien de Petit-Bost (Neuvic, Dordogne) a l'origine du Moustèrien d'Aquitanie? In: Jaubert, J., Bordes, J.G., Ortega, I. (Eds.), Les societies du Paléolothique dans un Grand Sud-Ouest de la France: nouveaux gisements, nouveaux resultants, nouvelles methods, Socièté Prèhistorique française. Mèmoire XLVII, pp. 41-55.

Cacho, C., Martos, J.A., 2002. Colecciones paleolíticas de Madrid en el Museo Arqueológico Nacional. In: Panera, J., Rubio-Jara, S. (Eds.), Bifaces y elefantes. La investigación del Paleolítico Inferior en Madrid, Zona Arqueológica, vol. 1, pp. 382-407.
Clark, J.D., 1994. The Acheulean industrial complex in Africa and elsewhere. In: Corruccini, R., Ciochon, R. (Eds.), Integrative Paths to the Past. Prentice Hall, New Jersey, pp. 451-469.

Cuartero, F., 2010. Estudio analítico de los percutores de TAFESA (Madrid). Adenda 1. In: Baena, J., Baquedano, I., (Coords.) (Eds.), Las huellas de nuestro pasado. Estudio del yacimiento del Pleistoceno Madrileño de Tafesa (Antigua Transfesa). Museo Arqueológico Regional de la Comunidad de Madrid. Zona Arqueológica, vol. 14, pp. 203-208.

De los Arcos, S., Gallego, N., Gil Ortiz, C., González García, I., Yravedra, J., 2008. Geoarqueología del yacimiento paleolítico del Estanque de Tormentas de Butarque (Villaverde, Madrid). OrJIA (Coord.). In: Actas de las I Jornadas de Jóvenes en Investigación Aqueológica. (Madrid, 3-5 septiembre de 2008). Dialogando con la cultura material, vol. I, pp. 135-140.

De los Arcos, S., Gallego, N., Gil Ortiz, C., González García, I., Yravedra, J., 2010. El nivel 4 (arcillas) del yacimiento paleolítico del Estanque de Tormentas de Butarque (Villaverde, Madrid). In: Actas de las $\mathrm{V}$ jornadas de patrimonio arqueológico en la Comunidad de Madrid. Celebradas en el Museo Arqueológico Regional de la Comunidad de Madrid del 12-14 de noviembre de 2008. Alcalá de Henares, Madrid, pp. 287-291.

Demuro, M., Arnold, L.J., Parés, J.M., Pérez-González, A., Ortega, A.I., Arsuaga, J.L., Bermúdez de Castro, J.M., Carbonell, E., 2014. New luminescence ages for the Galería Complex archaeological site: resolving chronological uncertainties on the Acheulean record of the Sierra de Atapuerca, Northern Spain. PLoS One 9 (10), e110169. http://dx.doi.org/10.1371/journal.pone, 0110169.

Díaz, M., Pérez-González, A., 1979. Estudio geológico de la terraza de Pinedo. In: Querol, M.A., Santonja, M. (Eds.), El yacimiento achelense de Pinedo (Toledo). Excavaciones Arqueológicas en España, 106. Ministerio de Cultura, Madrid, pp. 19-36.

Díez-Martín, F., Eren, M.I., 2012. The Early Acheulean in Africa: past paradigms, current ideas, and future directions. In: Domínguez-Rodrigo, M. (Ed.), Stone Tools and Fossil Bones. Current Debates in the Archaeology of Human Origins Cambridge. Cambridge University Press, pp. 310-357.

Díez-Martín, F., Sánchez-Yustos, P., Gómez-González, J.A., Gómez de la Rúa, D., 2008. Earlier Palaeolithic settlement patterns: landscape archaeology on the river Duero Basin Plateaus (Castilla y León, Spain). Journal of World Prehistory 21, $103-117$.

Domínguez Alonso, R.M., De los Arcos Fernández, S., Ruiz Zapata, B., Gil García, M.J., 2007. Terraza Compleja de Butarque en Villaverde. Póster IV Jornadas sobre Patrimonio Arqueológico de la Comunidad de Madrid. Celebradas en el Museo Arqueológico Regional de la Comunidad de Madrid en 2007. Alcalá de Henares, Madrid.

Domínguez Alonso, R.M., De los Arcos Fernández, S., Ruiz Zapata, B., Gil García, M.J., 2009. Nuevos datos sobre la Terraza Compleja de Butarque en Villaverde Bajo. IV Jornadas sobre Patrimonio Arqueológico de la Comunidad de MadridCelebradas en el Museo Arqueológico Regional de la Comunidad de Madrid en 2007. Alcalá de Henares, Madrid, pp. 339-343.

Doronichev, V., Golovanova, L., 2010. Beyond the Acheulean: a view on the Lower Paleolithic occupation of Western Eurasia. Quaternary International 223-224, $327-344$.

Falguères, C., Yokoyama, Y., Shen, G., Bischoff, J.L., Ku, T.L., Lumley, H. de, 2004. New U-series dates at the Caune de l'Arago, France. Journal of Archaeological Science 31, 941-952.

Gamazo, M., 2002. Las colecciones paleolíticas del Manzanares y del Jarama del Museo de San Isidro. In: Panera, J., Rubio Jara, S. (Eds.), Bifaces y elefantes. La investigación del Paleolítico Inferior en Madrid, Zona Arqueológica, vol. 1, pp. 358-381.

Gómez Hernanz, J., Márquez, B., Nicolás, E., Pérez-González, A., Ruiz Zapata, B., 2005. San Isidro (Madrid): 1862-2002. Nuevos hallazgos paleolíticos en la terraza de +30 m del río Manzanares. Trabajos de Prehistoria 62 (1), 157-164.

Goy, J.L., Pérez-González, A., Zazo, C., 1989. Cartografía geológica del Cuaternario, geomorfología y Memoria correspondiente de la Hoja a E, 1: 50.000 de Madrid (559). Instituto Tecnológico Geológico y Minero de España, Madrid.

Graells, Paz, de la, M., 1897. Fauna Mastodológica Ibérica. Memorias de la Real Academia de Ciencias Exactas, Físicas y Naturales de Madrid 17.

Isaac, G.L., 1969. Studies of early culture in East Africa. World Archaeology 1,1-27. Jiménez-Arenas, J.M., Santonja, M., Botella, M., Palmqvist, P., 2011. The oldest handaxes in Europe: fact or artefact? Journal of Archaeological Science 38, $3340-3349$

Kleindienst, M.R., 1962. Components of the East African Acheulean assemblage: an analytic approach. In: Mortelmans, G. (Ed.), Actes du IVème Congrès Panafricain de Préhistoire et de l'Etude du Quaternaire, 40. Musée Royal de l'Afrique Centrale, Tervuren (Belgique), pp. 81-105.

Koehler, H., 2008. L'apport du gisement des Osiers à Bapaume (Pas-de-Calais) au débat sur l'émergence du Paléolithique moyen dans le Nord de la France. Bulletin de la Société Prèhistorique Française 105 (4), 709-735.

Laplana, C., Herráez, E., Yravedra, J., Bárez, S., Rubio-Jara, S., Panera, J., Rus, I., PérezGonzález, A., 2015. Biocronología de la Terraza Compleja de Butarque del río Manzanares en el Estanque de Tormentas al sur de Madrid (España). Estudios Geológicos 71 (1), e028. http://dx.doi.org/10.3989/egeol.41808.338.

Leakey, M.D., 1975. Cultural patterns in the Olduvai sequence. In: Butzer, K.W., Isaac, G.L. (Eds.), After the Australopithecines. Mouton, Paris, pp. 477-493.

Lefèvre, D., Raynal, J.P., Vernet, G., Kieffer, G., Piperno, M., 2010. Tephro-stratigraphy and the age of ancient Southern Italian Acheulean settlements: the sites of Loreto and Notarchirico (Venosa, Basilicata, Italy). Quaternary International $223-224,360-368$ 
Lister, A.M., 1994. The evolution of the giant deer Megaloceros giganteus (Blumenbch). Zoological Journal of Linnean Society 112, 65-100.

López Martínez, N., 1980. Los micromamíferos (Rodentia, Insectivora, Lagomorpha Chiroptera), del sitio de ocupación Achelense de Áridos 1-1 (Arganda, Madrid). In: Santonja, M., López Martínez, N., Pérez-González, A. (Eds.), Ocupaciones Achelenses en el Valle del Jarama (Arganda, Madrid) Arqueología y Paleoecología, 1. Diputación Provincial de Madrid, pp. 161-202.

López-Recio, M., Silva, P.G., Roquero, E., Cunha, P.P., Tapias, F., Alcaraz-Castaño, M., Baena, J., Cuartero, F., Morín, J., Torres, T., Ortiz, J.E., Murray, A.S., Buylaert, J.P., 2015. Geocronología de los yacimientos achelenses de Pinedo y Cien Fanegas (Valle del Tajo) e implicaciones en la evolución fluvial en el entorno de Toledo (España). Estudios Geológicos 71 (1), e029. http://dx.doi.org/10.3989/egeol. 41816.340

Made, J. van der, 2001. Les Ongulés d'Atapuerca. Stratigraphie et biogéographie. L'Anthropologie 105 (1), 95-113.

Manzano, L., Expósito, A., Pérez-González, A., Soto, E., Sesé, C., Yravedra, J., RuizZapata, B., Millán, A., Benéitez, P., Torres, T., Mondéjar, J.A., Zarco, E., Sánchez, H., Citores, A., Ramos, M., Rodríguez, A., 2010. El yacimiento arqueo-paleontológico de EDAR Culebro 1 (Estación Depuradora de Aguas Residuales de la Cuenca Baja del Arroyo Culebro. In: Ministerio de Medio Ambiente Confederación Hidrógráfica del Tajo. Actas de las V jornadas de patrimonio arqueológico en la Comunidad de Madrid. Celebradas en el Museo Arqueológico Regional de la Comunidad de Madrid del 12-14 de noviembre de 2008. Alcalá de Henares, Madrid, pp. 203-214.

Mazo, A.V., 2010. Los macrovertebrados del Pleistoceno Medio del yacimiento de TAFESA (Madrid). In: Baena, J., Baquedano, I., (Coords.) (Eds.), Las huellas de nuestro pasado. Estudio del yacimiento del Pleistoceno Madrileño de Tafesa (Antigua Transfesa), vol. 14. Museo Arqueológico Regional de la Comunidad de Madrid, Zona Arqueológica, pp. 141-153.

Meléndez, B., Aguirre, E., 1958. Hallazgo de Elephas en la terraza media del río Manzanares (Villaverde, Madrid). Las Ciencias XXIII (4), 597-605.

Moncel, M.H., Moigne, A.M., Combier, J., 2005. Pre-Neanderthal behaviour during isotopic 9 and beginning of stage 8. New data concerning fauna and lithics in the different occupation levels of Orgnac 3 (Ard eche, South-East France). Journal of Archaeological Science 32, 1283-1301.

Moncel, M.H., Desprièe, J., Voinchet, P., Tissoux, H., Moreno, D., Bahain, J.J., Falguères, C., 2013. Early evidence of Acheulean settlement in Northwestern Europe-La Noira site, a 700000 year-old occupation in the Center of France. Plos One 8 (11), e75529.

Moncel, M.H., Despriée, J., Voinchet, P., Courcimault, G., Hardy, B., Bahain, J.-J., Puaud, S., Gallet, X., Falguères, C., 2015. The Acheulean workshop of la Noira (France, $700 \mathrm{ka}$ ) in the European technological context. Quaternary International. http://dx.doi.org/10.1016/j.quaint.2015.04.051.

Moreno, D., Falguères, C., Pérez-González, A., Duval, M., Voinchet, Pl, BenitoCalvo, A., Ortega, A.I., Bahain, J.-J., Sala, R., Carbonell, E., Bermúdez de Castro, J.M., Arsuaga, J.L., 2012. ESR chronology of alluvial deposits in the Arlanzón valley (Apuerca, Spain): contemporaneity with Atapuerca Gran Dolina site. Quaternary Geochronology. http://dx.doi.org/10.1016/j.quageo. 2012.01018.

Mosquera, M., Ollé, A., Saladié, P., Cáceres, I., Huguet, R., Rosas, A., Villalaín, J., Carrancho, A., Bourlès, D., Braucher, R., Pineda, A., Vallverdú, J., 2015. The Early Acheulean technology of Barranc de la Boella (Catalonia, Spain). Quaternary International. http://dx.doi.org/10.1016/j.quaint.2015.05.005.

Mourre, V., 2003. Implication culturelles de la technologie des hachereaux. Université de Paris X, Nanterre, Paris.

Obermaier, H., 1925. El Hombre Fósil. (2 ${ }^{\mathrm{a}}$ reedición ampliada), 2ª edición. Ediciones Istmo, Madrid. Re-edición facsimilar de la.

Ollé, A., 2005. Variabilitat i patrons funcionals en els sistemes tècnics de mode 2. Anàlisi de les deformacions d'ús en els conjunts lítics del Riparo Esterno de Grotta Paglicci (Rigano Garganico, Foggia), Áridos (Arganda, Madrid) i GaleriaTN (Atapuerca, Burgos). Universitat Rovira i Virgili (PhD dissertation). http:// www.tdx.cesca.es/TDX-0701105-120553.

Ollé, A., Mosquera, M., Rodríguez, X.P., de Lombera-Hermida, A., García-Anton, M.D. García-Medrano, P., Peña, L., Menéndez, L., Navazo, M., Terradillos, M., Bargallo, A., Marquez, B., Sala, R., Carbonell, E., 2013. The Early and Middle Pleistocene Technological Record from Sierra de Atapuerca (Burgos, Spain). Quaternary International 295, 138-167.

Panera, J., 2009. La ocupación del medio fluvial en el Paleolítico antiguo. Caracterización geoarqueológica de depósitos pleistocenos del valle del río Jarama (Madrid) y estudio tecnoeconómico de la industria lítica. Departamento de Prehistoria y Arqueología. Facultad de Geografía e Historia. Universidad Nacional de Educación a Distancia (Tesis Doctoral inédita).

Panera, J., Pérez-González, A., Rubio-Jara, S., Sesé, C., 2005. El yacimiento paleolítico de HAT en el valle del Jarama: una aportación de Cuaternario de la cuenca de Madrid al debate sobre el inicio del Paleolítico medio. In: Santonja, M., PérezGonzález, A., Machado, M.J. (Eds.), Geoarqueología y Patrimonio en la Península Ibérica y el entorno Mediterráneo ADEMA, Soria, pp. 251-260.

Panera, J., Torres, T., Pérez-González, A., Ortiz, J.E., Rubio-Jara, S., Uribelarrea, D., 2011. Geocronología de la Terraza Compleja de Arganda en el valle del río Jarama (Madrid, España). Estudios Geológicos 67 (2), 495-504.

Panera, J., Rubio-Jara, S., Yravedra, J., Hugues-Alexandre, B., Sesé, C., PérezGonzález, A., 2014. Manzanares Valley (Madrid, Spain): a good country for Proboscideans and Neanderthals. Quaternary International 326-327, 329-343.

Parfitt, S.A., Ashton, N.M., Lewis, S.G., Abel, R.L., Coope, G.R., Field, M.H., Gale, R., Hoare, P.G., Larkin, N.R., Lewis, M.D., Karloukovski, V., Maher, B.A., Peglar, S.M., Preece, R.C., Whittaker, J.E., Stringer, C.B., 2010. Early Pleistocene human occupation at the edge of the boreal zone in northwest Europe. Nature 466, 229-233.

Pereira, A., Nomade, S., Voinchet, P., Bahain, J.J., Falguères, C., Garon, H., Piperno, M., 2015. The earliest securely dated hominin fossil in Italy and evidence of Acheulian occupation during glacial MIS 16 at Notarchirico (Venosa, Basilicata, Italy). Journal of Quaternary Science 30 (7), 639-650.

Pérez-González, A., 1971. Estudio de los procesos de hundimiento en el valle del río Jarama y sus terrazas (nota preliminar). Estudios Geológicos XXVII (4), 317-324.

Pérez-González, A., 1980. Geología y estratigrafía de los yacimientos de Aridos en la llanura aluvial de Arganda (Madrid). In: Santonja, M., López, N., PérezGonzález, A. (Eds.), Ocupaciones achelenses en el valle del Jarama. Arqueología y Paleontología, I. Diputación Provincial de Madrid, pp. 49-61.

Pérez-González, A., 1994. In: Elorza, Gutiérrez (Ed.), Depresión del Tajo. Geomorfología de España, Rueda, pp. 389-436.

Pérez-González, A., Uribelarrea del Val, D., 2002. Geología del Cuaternario de los valles fluviales del Jarama y Manzanares en las proximidades de Madrid. In: Panera, J., Rubio-Jara, S. (Eds.), Bifaces y elefantes. La investigación del Paleolítico Inferior en Madrid, Zona Arqueológica, vol. 1, pp. 303-317.

Pérez-González, A., Rubio-Jara, S., Panera, J., Uribelarrea, D., 2008. Geocronología de la sucesión arqueoestratigráfica de Los Estragales en la Terraza Compleja de Butarque (Valle del río Manzanares, Madrid). Geogaceta 45, 39-42.

Pérez-González, A., Gallardo-Millán, J.L., Uribelarrea del Val, D., Panera, J., RubioJara, S., 2013. La inversión Matuyama-Brunhes en la secuencia de terrazas del río Jarama entre Velilla de San Antonio y Altos de la Mejorada, al SE de Madrid (España). Estudios Geológicos 69 (1), 35-46. http://dx.doi.org/10.3989/ egeol.40862.173 enero-junio 2013.

Pinilla, L., Pérez-González, A., Sopeña, A., Parés, J.M., 1995. Fenómenos de hundimiento sinsedimentarios en los depósitos cuaternarios del río Tajo en la provincia de Madrid (Almoguera-Fuentidueña de Tajo). In: Aleixandre, T., Pérez González, A. (Eds.), Reconstrucción de paleoambientes y cambios climáticos durante el Cuaternario Monografías del Centro de Ciencias Medioambientales, vol. 3, pp. 125-139.

Quero Castro, S., 2002. La investigación del Paleolítico en Madrid durante el franquismo. In: Panera, J. Rubio-Jara, S. (Eds.), Bifaces y elefantes, La investigación del Paleolítico Inferior en Madrid. Zona Arqueológica, vol. 1. Museo Arqueológico Regional de la Comunidad de Madrid, Madrid, pp. 168-193.

Querol, M.A., Santonja, M., 1979. El yacimiento achelense de Pinedo (Toledo). Excavaciones Arqueológicas en España, vol. 106. Ministerio de Cultura, Madrid, p. 181.

Richter, J., 2011. When did the middle Palaeolithic begin? In: Conard, N.J., Richter, J (Eds.), Neanderthal Lifeways, Subsistence and Technology: One Hundred Fifty Years of Neanderthal Study, Vertebrate Paleobiology and Paleoanthropology. Springer Science Business Media B.V, pp. 7-14.

Roche, H., Brugal, J.-P., Delagnes, A., Feibel, C., Harmand, S., Kibunjia, M., Prat, S. Texier, P.-J., 2003. Les sites archéologiques plio-plésitocènes de la formation de Nachukui, Ouest-Turkana, Kenya: Bilan synthétique 1997-2001. Comptes Rendus Palevol 2, 663-673.

Rodríguez de Tembleque, J.M., 1997. Ocupación humana en el interior de la Península Ibérica durante el pleistoceno medio: Una aproximación al sector oriental de la Submeseta norte y su borde meridional. Universidad Autónoma de Madrid (Tesis de Licenciatura).

Rodríguez de Tembleque, J.M., 2004. Yacimiento de Puente Pino: Nuevas perspectivas para el estudio del Paleolítico inferior en la Península Ibérica. In: Baquedano, E., Rubio-Jara, S. (Eds.), Miscelánea en Homenaje a Emiliano Aguirre, IV. Zona Arqueológica, vol. 4, pp. 441-450.

Rodríguez de Tembleque, J.M., 2005a. El Paleolítico inferior en la cuenca del Tajo (Castilla-La Mancha). In: Los Primeros Pobladores de Castilla-La Mancha, pp. 112-139. Fundación Cultura y Deporte de JCCM y Caja de Castilla-La Mancha (Eds).

Rodríguez de Tembleque, J.M., 2005b. Industrias achelenses en el sudeste de la Submeseta norte y su borde meridional. In: Santonja, M., Pérez-González, A (Eds.), Los yacimientos paleolíticos de Torralba y Ambrona (Soria). Un siglo de investigaciones. Zona Arqueológica, vol. 5, pp. 334-350.

Rodríguez de Tembleque, J.M., 2008. Primeras ocupaciones humanas en la Meseta española: Estudio geoarqueológico de depósitos fluviales en la cuenca media del Tajo. Universidad Autónoma de Madrid, Madrid (España). Servicio de Publicaciones de la UAM (formato digital), p. 843 (Tesis Doctoral).

Rodríguez de Tembleque, J.M., Santonja, M., Pérez-González, A., 2007-2008. Las industrias líticas en depósitos fluviales pleistocenos de la Cuenca Media del Tajo: área de Talavera de la Reina (Toledo). Veleia 24-25, 345-366.

Rodríguez de Tembleque, J.M., Pérez-González, A., Santonja, M., 2010. Indicios de presencia humana en la Meseta Ibérica durante la formación de la Terraza de +75-80 m del Río Tajo. In: Cuaternario y Arqueología: Homenaje a Francisco Giles PachecoAsociación Profesional del Patrimonio Histórico-Arqueológico de Cádiz. Servicio de Publicaciones de la Diputación Provincial de Cádiz, pp. $45-54$.

Rolland, N., 1995. Levallois technique emergence: single or multiple? A review of the Euro-African record. In: Dibble, H.L., Bar-Yosef, O. (Eds.), The Definition and nterpretation of Levallois Technology, vol. 23. Prehistory Press, Madison Wisconsin, pp. 333-359.

Roquero, E., Goy, J.L., Zazo, C., 1999. Fenómenos de convergencia genética en suelos de terrazas fluviales: Valle del Río Tajo, Madrid-Toledo (España). Revista de la Sociedad Geológica de España 12 (3-4), 329-338.

Rubio-Jara, S., 1996. Identificación de cadenas operativas líticas en el Complejo Superior de Ambrona (Soria). Complutum 7, 37-50. 
Rubio-Jara, S., 2011. El paleolítico en el valle del río Manzanares (Madrid) Caracterización geoarqueológica de depósitos pleistocenos y estudio tecnoeconómico de la industria lítica. Universidad Nacional de Educación a Distancia (Tesis Doctoral inédita)

Rubio-Jara, S., Panera, J., Martos, J.A., 1999. Autopistas, Ferrocarriles y Bifaces: nuevas perspectivas para la investigación del Paleolítico en los ríos Manzanares y Jarama? Espacio, Tiempo y Forma. Prehistoria y Arqueología I (12) 67-79.

Rubio-Jara, S., Panera, J., Martos, J.A., Santonja, M., Pérez-González, A., 2002. Revisión crítica y síntesis del Paleolítico de los valles del Manzanares y Jarama. In Panera, J., Rubio-Jara, S. (Eds.), Bifaces y elefantes. La investigación del Paleolítico Inferior en Madrid. Museo Arqueológico Regional de la Comunidad de Madrid, Zona Arqueológica, vol. 1, pp. 338-355.

Ruiz Zapata, M.B., Rodríguez de Tembleque, J.M., Pérez González, A., Gil García, M.J., 2009. Paleovegetación en el yacimiento achelense de Puente Pino y su entorno Toledo, España. Revista de Cuaternario y Geomorfología 23 $(1-2), 113-126$.

Rus, I., 1989. El paleolítico inferior en el valle del Manzanares. Raña 7, 33-34.

Rus, I., Querol, M.A., 1981. El arenero de Oxígeno: bifaces, hendedores y triedros conservados en el Museo Arqueológico Nacional. Trabajos de Prehistoria 38, $39-67$.

Sahnouni, M., Semaw, S., Rogers, M., 2013. The African Acheulean. An archaeological summary. In: Mitchell, P., Lane, P. (Eds.), The Oxford Handbook of African Archaeology. Oxford University Press, Oxford, pp. 307-323.

Santonja, M., 1977. Los bifaces del Cerro de San Isidro conservados en el Museo Arqueológico Nacional. Revista de Archivos, Bibliotecas y Museos 80 (1), 147-182.

Santonja, M., 1981a. El Paleolítico inferior de la Meseta central española. Universidad Complutense de Madrid (Tesis Doctoral).

Santonja, M., 1981b. Características generales del Paleolítico inferior de la Meseta Española. Numantia 1, 9-64.

Santonja, M., Pérez-González, A., 1997. Los yacimientos achelenses en terrazas fluviales de la Meseta Central española. In: Rodríguez Vidal, J. (Ed.), Cuaternario Ibérico 224-234.

Santonja, M., Pérez-González, A., 2000-2001. El Paleolítico inferior en el interior de la Península Ibérica. Un punto de vista desde la Geoarqueologia. Zephyrus 53-54, 27-77.

Santonja, M., Pérez-González, A., 2006. La industria lítica del miembro estratigráfico medio de Ambrona (Soria, España) en el contexto del Paleolítico Antiguo de la Península Ibérica. Zephyrus LIX 7-20.

Santonja, M., Pérez-González, A., 2010. Mid-Pleistocene Acheulean industrial complex in the Iberian Peninsula. Quaternary International 223-224, $154-161$.

Santonja, M., Querol, M.A., 1977. La gravera cuaternaria de las Acacias en el río Jarama (Mejorada del Campo). In: Actas del XIV Congreso de Arqueología Nacional (Vitoria 1975), Zaragoza, pp. 49-56.

Santonja, M., Querol, M.A., 1980. Las industrias achelenses en la región de Madrid. In: Santonja, M., López, N., Pérez-González, A. (Eds.), Ocupaciones achelenses en el valle del Jarama (Arganda, Madrid). Arqueología y Paleoecología I. Diputación Provincial de Madrid, pp. 29-48.

Santonja, M., Querol, M.A., 1982. Industrias de Paleolítico Inferior Arcaico en la Meseta Española. In: Homenaje a Concepción Fernández Chicharro, Ministerio de Cultura, pp. 17-31.

Santonja, M., Vega, L.G., 2002. La investigación del valle del Manzanares (1862-1975) en el contexto del Paleolítico español. In: Panera, J., Rubio-Jara, S. (Eds.), Bifaces y elefantes. La investigación del Paleolítico Inferior en Madrid. Zona Arqueológica I. Museo Arqueológico Regional de la Comunidad de Madrid pp. $242-275$

Santonja, M., Villa, P., 2006. The Acheulean of western Europe. In: Goren-Inbar, N. Sharon, G. (Eds.), Axe Age. Acheulean Toolmaking from Quarry to Discard Equinox, London, pp. 429-478.

Santonja, M., López Martínez, N., Pérez-González, A. (Eds.), 1980. Ocupaciones Achelenses en el Valle del Jarama (Arganda, Madrid). Arqueología y Paleoecología 1, Diputación Provincial de Madrid, p. 352.

Santonja, M. Pérez-González, A., Vega Toscano, G., Rus, I, 2001. Elephants and stone artifacts in the Middle Pleistocene terraces of the Manzanares river (Madrid, Spain). In: TheWorld of Elephants. Proceedings of the I International Congress Roma, 16e20 October, 2001, pp. 597-601.

Santonja, M., Pérez-González, A., Domínguez-Rodrigo, M., Panera, J., Rubio-Jara, S. Sesé, C., Soto, E., Arnold, L.J., Duval, M., Demuro, M., Ortiz, J.E., de Torres, T. Mercier, N., Barba, R., Yravedra, J., 2014. The Middle Paleolithic site of Cuesta de la Bajada (Teruel, Spain): a perspective on the Acheulean and Middle Paleolithic techno-complexes in Europe. Journal of Archaeological Science 49, 556-571.

Santonja, M., Pérez-González, A., Panera, J., Rubio-Jara, S., Méndez-Quintas, E., 2015 The coexistence of Acheulean and Ancient Middle Palaeolithic technocomplexes in the Middle Pleistocene of the Iberian Peninsula. Quaternary International. http://dx.doi.org/10.1016/j.quaint.2015.04.056.

Semaw, S., Rogers, M., Stout, D., 2009. The Oldowan-Acheulean transition: is there a "Developed Oldowan" tradition? In: Camps, M., Chauhan, P. (Eds.), Sourcebook of Palaeolithic Transitions. Springer, New York, pp. 173-193.

Sese, C., 2010. Micromamíferos del yacimiento del Pleistoceno Medio de Tafesa (Madrid). In: Baena, J., Baquedano, I., (Coords.) (Eds.), Las huellas de nuestro pasado. Estudio del yacimiento del Pleistoceno Madrileño de Tafesa (Antigua Transfesa). Museo Arqueológico Regional de la Comunidad de Madrid. Zona Arqueológica, vol. 14, pp. 137-139.
Sese, C., Lopez-Martínez, N., 2013. Nuevos datos paleontológicos del Pleistoceno en el Valle del Manzanares (Madrid, España): Los micromamíferos del yacimiento del Arenero de Arriaga. Estudios Geológicos 69 (2), 271-282.

Sese, C., Soto, E., 2000. Vertebrados del Pleistoceno de Madrid. In: Morales, J. (Ed.), (Coord.). Patrimonio paleontológico de la Comunidad de Madrid. Arqueología, Paleontología y Etnografía 6, Comunidad de Madrid, pp. 215-243.

Sese, C., Soto, E., 2002. Catálogo de los yacimientos de Vertebrados del Pleistoceno en las terrazas de los ríos Jarama y Manzanares. In: Panera, J., Rubio-Jara, S. (Eds.), Bifaces y elefantes. La investigación del Paleolítico Inferior en Madrid, Zona Arqueológica, vol. 1, pp. 430-457.

Sese, C., Soto, E., Perez-Gonzalez, A., 2000. Mamiferos de las terrazas del valle del Tajo: primeros datos de micromamíferos del Pleistoceno en Toledo (España Central). Geogaceta 28, 133-136.

Sese, C., Aparicio, M.T., Perez-Gonzalez, A., 2004. Moluscos y microvertebrados del Pleistoceno de las terrazas del río Tajo en Toledo y Fuentidueña de Tajo (España Central). Geogaceta 36, 183-186.

Sese, C. Panera, J., Rubio-Jara, S., Pérez-González, A., 2011. Micromamíferos del Pleistoceno Medio y Pleistoceno Superior en el Valle del Jarama: Yacimientos de Valdocarros y HAT (Madrid). Estudios Geológicos 67 (1), 131-151.

Sharon, G., 2010. Large flake Acheulian. Quaternary International 223-224, 226-233.

Sharon, G., 2011. Flakes crossing the straits?. Entame flakes and Northern Africa -Iberia contact during the Acheulean. African Archaeological Review 28 (2), 125-140.

Silva, P.G., 2003. El valle inferior del Manzanares (Cuenca de Madrid, España). Volumen en Homenaje a D. Manuel Hoyos. Estudios Geológicos 59, 107-131.

Silva, P., Goy, J.L., Zazo, C., 1988a. Neotectónica del sector centro-meridional de la Cuenca de Madrid. Estudios Geológicos 2, 133-136.

Silva, P.G., Goy, J.L., Zazo, C., Hoyos, M., Alberdi, M.T., 1988b. In: El valle del Manzanares y su relación con la depresión Prados-Guaten durante el Pleistoceno inferior (Madrid, España). II Congreso geológico de España. Comunicaciones, vol. 1 (Granada, 1988), pp. 403-406.

Silva, P.G., Cañaveras, J., Sánchez-Moral, S., Lario, J., Sanz, E., 1997. 3d soft sediment deformation structures: evidence for quaternary seismicity in the Madrid basis, Spain. Terra Nova 9 (5/6), 208-212.

Silva, P.G., Lario, J., Cañaveras, J.C., Sánchez Moral, S., Sanz, E., 2010. Geología, geomorfología y sedimentología de los depósitos cuaternarios del yacimiento de TAFESA (Madrid). In: Baena, J., Baquedano, e I., (Coords.) (Eds.), Las huellas de nuestro pasado. Estudio del yacimiento del Pleistoceno Madrileño de Tafesa (Antigua Transfesa). Museo Arqueológico Regional de la Comunidad de Madrid. Zona Arqueológica, vol. 14, pp. 15-35.

Silva, P.G., López-Recio, M., Tapias, F., Roquero, E., Morín, J., Rus, I., CarrascoGarcía, P., Giner-Robles, J.L., Rodríguez-Pascua, M.A., Pérez-López, R., 2012. Stratigraphy of the Arriaga Palaeolithic sites. Implications for the geomorphological evolution recorded by thickened fluvial sequences within the Manzanares River valley (Madrid Neogene Basin, Central Spain). Geomorphology. http://dx.doi.org/10.1016/j.geomorph.2012.10.019.

Tavoso, A. 1986. Le Paléolithique inférieur et moyen du Haut-Languedoc. Gisements des terrasses alluviales du Tarn, du Dadou, de l'Agout, du Sor et du Fresquel. Etudes Quaternaires 5 (1978), 404. Université de Provence, Ed. du Laboratoire de Paléontologie Humaine et de Préhistoire.

Tixier Inizan, J.P., 1956. Le hachereau dans l'Acheuléen Nord-Africain. Notes typologiques. In: Congrès Préhistorique de France (Poitiers 1956), pp. 914-923.

Toro, I., Barsky, D., Cauche, D., Celiberti, V., Grégoire, S., Lebegue, F., Moncel, M.H., Lumley, H. de, 2011. The archaic stone tool industry from Barranco León and Fuente Nueva 3 (Orce, Spain): evidence of the earliest hominin presence in southern Europe. Quaternary International 243, 80-91.

Turq, A., Brenet, M., Colonge, D., Jarry, M., Lelouvier, L.A., O'Farrel, M., Jaubert, J. 2010. The first human occupations in southwestern France: a revised summary twenty years after the Abbeville/Saint Riquier colloquium. Quaternary International 223-224, 383-398.

Uribelarrea, D., 2008. Dinámica y evolución de las llanuras aluviales de los ríos Manzanares, Jarama y Tajo, entre las ciudades de Madrid y Toledo. Universidad Complutense de Madrid. Facultad de Ciencias Geológicas. Departamento de Geodinámica, p. 396 (Tesis Doctoral).

Vallverdú, J., Saladiè, P., Rosas, A., Huguet, R., Cáceres, I., Mosquera, M., GarciaTabernero, A., Estalrrich, A., Lozano-Fernández, I., Pineda-Alcalá, A., Carrancho, A., Villalaín, J.J., Bourles, D., Braucher, R., Lebatard, A., Vilalta, J., Esteban-Nadal, M., Bennàsar, M.L., Bastir, M., López-Polín, L., Ollé, A., Vergès, J.M., Ros-Montoya, S., Martínez-Navarro, B., García, A., Martinell, J., Expósito, I., Burjachs, F., Agustí, J., Carbonell, E., 2014. Age and date for Early Arrival of the Acheulian in Europe (Barranc de la Boella, la Canonja, Spain). PLoS One 9 (7), e103634. http://dx.doi.org/10.1371/journal.pone.0103634.

Verneuil, E., Lartet, E., 1863. Note sur un silex taillé trouvé dans le diluvium des environs de Madrid. Bulletin de la Societé Géologique de France, pp. 698-702, $2^{\text {a }}$ Serie, $\mathrm{XX}$.

Yravedra, J., 2010. Estudio tafonómico y zooarqueológico de los macromamíferos del yacimiento arqueológico de TAFESA (Madrid). In: Baena, J., Baquedano, I., (Coords.) (Eds.), Las huellas de nuestro pasado. Estudio del yacimiento del Pleistoceno Madrileño de Tafesa (Antigua Transfesa). Museo Arqueológico Regional de la Comunidad de Madrid. Zona Arqueológica, vol. 14, pp. 155-176.

Yravedra, J., Domínguez-Rodrigo, M., 2009. The shaft-based methodological approach to the quantification of long limb bones and its relevance to understanding hominid subsistence in the Pleistocene: application to four Palaeolithic sites. Journal of Quaternary Science 24, 85-96. 
Yravedra, J., Domínguez-Rodrigo, M., Santonja, M., Pérez- González, A., Panera, J., Rubio-Jara, S., Baquedano, E., 2010. Cut marks on the Middle Pleistocene elephant carcass of Áridos 2 (Madrid, Spain). Journal of Archaeological Science 37, 2469-2476.
Yravedra, J., Rubio-Jara, S., Panera, J., Uribelarrea, D., Pérez-González, A., 2012. Elephants and subsistence. Evidence of the human exploitation of extremely large mammal bones from the Middle Palaeolithic site of PRERESA (Madrid, Spain). Journal of Archaeological Science 39, 1063-1071.

Please cite this article in press as: Rubio-Jara, S., et al., Large flake Acheulean in the middle of Tagus basin (Spain): Middle stretch of the river Tagus valley and lower stretches of the rivers Jarama and Manzanares valleys, Quaternary International (2015), http://dx.doi.org/10.1016/ 